\title{
The Nucleosome: Orchestrating DNA Damage Signaling and Repair within Chromatin
}

\begin{tabular}{|c|c|}
\hline Journal: & Biochemistry and Cell Biology \\
\hline Manuscript ID & bcb-2016-0017.R1 \\
\hline Manuscript Type: & Mini Review \\
\hline Date Submitted by the Author: & 17-Mar-2016 \\
\hline Complete List of Authors: & $\begin{array}{l}\text { Agarwal, Poonam; University of Texas at Austin, Molecular Biosciences } \\
\text { Miller, Kyle; University of Texas at Austin, Molecular Biosciences; }\end{array}$ \\
\hline Keyword: & $\begin{array}{l}\text { DNA double-strand break repair, DNA damage response, nucleosome acidic } \\
\text { patch, chromatin, histone modifications }\end{array}$ \\
\hline
\end{tabular}

\section{SCHOLARONE" \\ Manuscripts}


The Nucleosome: Orchestrating DNA Damage Signaling and Repair within Chromatin

Poonam Agarwal ${ }^{1} \&$ Kyle M. Miller ${ }^{1, *}$

${ }^{1}$ Department of Molecular Biosciences, Institute for Cellular and Molecular Biology, University of Texas at Austin, 2506 Speedway Stop A5000, Austin, TX 78712 USA.

${ }^{*}$ Corresponding author. K.M.M.

Contact information: University of Texas at Austin Institute for Cellular and Molecular Biology Department of Molecular Biosciences 2506 Speedway Stop A5000

Austin, TX 78712 USA Tel: +1512 471-5045 (office) email: kyle.miller@austin.utexas.edu

\section{Key words}

DNA double-strand break repair, DNA damage response, nucleosome acidic patch, chromatin, histone modifications 


\section{Abstract}

DNA damage occurs within the chromatin environment, which ultimately participates in regulating DNA damage response (DDR) pathways and repair of the lesion. DNA damage activates a cascade of signaling events that extensively modulates chromatin structure and organization to coordinate DDR factor recruitment to the break and repair whilst also promoting the maintenance of normal chromatin functions within the damaged region. For example, DDR pathways must avoid conflicts between other DNA-based processes that function within the context of chromatin including transcription and replication. The molecular mechanisms governing the recognition, target specificity and recruitment of DDR factors and enzymes to the fundamental repeating unit of chromatin, i.e., the nucleosome, are poorly understood. Here, we present our current view for how chromatin recognition by DDR factors is achieved at the level of the nucleosome. Emerging evidence suggests that the nucleosome surface, including the nucleosome acidic patch, promotes the binding and activity of several DNA damage factors on chromatin. Thus, in addition to interactions with damaged DNA and histone modifications, nucleosome recognition by DDR factors plays a key role in orchestrating the requisite chromatin response to maintain both genome and epigenome integrity. 


\section{Introduction}

Maintenance of genomic integrity through the preservation of genetic information is crucial for organismal survival and homeostasis. Genomic instability can be caused by high incidences of DNA damage that occur frequently in cells as a consequence of recurrent exposure to genotoxic cellular processes and agents including replication stress, reactions involving metabolic by-products, transcription-associated damage and exposure to external factors including UV radiation, environmental agents and clinical treatments like radiotherapy and chemotherapeutics (Ciccia and Elledge 2010; Jackson and Bartek 2009). DNA damage must be detected and repaired in a timely and efficient manner to avert genomic and cellular alterations that can cause diseases including cancer (Jackson and Bartek 2009). To combat the harmful effects posed by DNA damage, cells use a highly coordinated network of DNA damage response (DDR) pathways to detect the damaged DNA lesion, signal its presence to downstream effector proteins, which orchestrate the appropriate cellular responses and DDR pathways to repair the lesion (Ciccia and Elledge 2010; Jackson and Bartek 2009). Nuclear eukaryotic DNA is bound by histone proteins and structurally organized into chromatin through the formation of nucleosomes, the basic unit of chromatin that contains 2 copies each of the 4 core histones and $\sim 146$ bp of DNA. Chromatin therefore constitutes the legitimate in vivo substrate in which all processes involving DNA occur including DNA replication, transcription and DNA repair. Thus, the DNA damage response and repair machinery that operates at the sites of DNA damage must function 
within the context of chromatin. It is well-established that a multitude of DNA repair factors are recruited to chromatin upon DNA damage and that chromatin features including chromatin architecture, histone modifications, histone variants and chromatin remodeling complexes shape the epigenetic landscape to orchestrate DNA repair reactions within the chromatin environment (Miller and Jackson 2012; Polo and Jackson 2011; Smeenk and van Attikum 2013; Soria et al. 2012). What is less clear however is how specificity for chromatin binding and modification of histones by DDR factors is achieved within chromatin to promote DNA damage signaling and repair. In this review, we will summarize our current understanding of the interplay between chromatin dynamics and DNA repair with a focus on DNA double-strand break (DSB) repair in mammalian cells. We will also discuss recent findings that suggest that the topology and interaction surfaces of the nucleosome, including the nucleosome acidic patch, act as chromatin interaction platforms that govern the site-specific modification of histones and chromatin dynamics involved in the DDR. We aim to provide a comprehensive examination of DDR factor interactions that occur at the level of the nucleosome so as to explore mechanistically how the fundamental unit of chromatin, the nucleosome, initiates DNA damage signaling to coordinate DDR activities including DNA repair.

\section{Chromatin dynamics and DNA repair}

\section{DNA double-strand break repair (DSBR)}


DNA double-strand breaks (DSB) are considered a particularly dangerous DNA lesion as failure to repair the broken ends accurately can promote genomic instability through chromosome loss, rearrangements and/or mutations. DSBs are repaired by two prominent repair pathways in mammalian cells, namely, homologous recombination (HR) or non-homologous end-joining (NHEJ) (Huertas 2010). The two repair pathways differ in their requirement for a homologous template DNA and in the fidelity of DSB repair. HR uses an undamaged sister chromatid sequence as a template to faithfully repair the DSB while NHEJ is a potentially more error-prone pathway that repairs the break through ligating the broken ends together. In mammalian cells, NHEJ is the predominant repair pathway active throughout the cell cycle while HR is restricted to S/G2 phases, cell cycle stages in which a sister chromatid is available for repair (Beucher et al. 2009; Lieber 2010; San Filippo et al. 2008). Control of these two pathways necessitates the regulation of chromatin/nucleosome modifications that take place surrounding the break. Histone post-translational modifications (PTMs), histones exchange and nucleosome remodelling complexes participate in altering the chromatin landscape to facilitate DDR activities, which ultimately lead to the repair of the damaged DNA. Whether the damaged lesion is repaired by NHEJ or HR pathway, detection of the damaged DNA and initiation of either of these DSB repair processes requires recruitment of chromatin modifying enzymes for remodeling of the damaged chromatin. Histone modifications serve as one mechanism that opens or condenses the chromatin structure by changing the 
nucleosome-DNA, nucleosome-nucleosome and/or nucleosome/chromatin protein interactions. ATP-dependent chromatin remodelers alter the chromatin landscape by either sliding, evicting or exchanging histones including variants or modulating nucleosome-DNA interactions to promote DNA damage signaling and repair (Kouzarides 2007; Luijsterburg and van Attikum 2011; Miller and Jackson 2012; Misteli and Soutoglou 2009; Price and D'andrea 2013; Seeber et al. 2013). The collective utilization of these pathways is essential for maintaining genome integrity and averting diseases including cancer.

\section{Histone PTMs}

Histone PTMs can impact chromatin structure to provide DNA accessibility to DDR factors to facilitate repair. Histone PTMs including phosphorylation, ubiquitylation, methylation and acetylation can also serve as molecular DSB recognition signals for PTM "reader" proteins that selectively recognize and bind to these modifications on chromatin (Kouzarides 2007; Miller and Jackson 2012; Musselman et al. 2012; Ruthenburg et al. 2007; van Attikum and Gasser 2005). For example, the first histone signaling event identified upon DSB induction was the phosphorylation on serine-139 of the histone variant $\mathrm{H} 2 \mathrm{AX}$ (called $\gamma \mathrm{H} 2 \mathrm{AX}$ ) (Rogakou et al. 1998). This modification is triggered by the activation of the DDR kinases, including ATM and DNA-PK, that are themselves recruited to and activated by signaling processes that include DNA ends of the DSB. Although initiated at the DSB, the $\gamma \mathrm{H} 2 \mathrm{AX}$ modification spreads over a megabase of chromatin flanking the DSB site by an amplification loop involving the binding of 
$\gamma \mathrm{H} 2 \mathrm{AX}$ by the phospho-reader MDC1, which interacts with MRN complex to recruit and further stimulate ATM activity on chromatin (Fig. 1A) (Burma et al. 2001; Chapman and Jackson 2008; Lukas et al. 2004; Rogakou et al. 1999; Rogakou et al. 1998; Savic et al. 2009; Scully and Xie 2013; Sedelnikova et al. 2002; Stucki et al. 2005). Focal accumulation of $\gamma \mathrm{H} 2 \mathrm{AX}$ promotes the accumulation of DSB factors to the break site, thereby promoting chromatin responses to DNA damage (Celeste et al. 2002; Fernandez-Capetillo et al. 2003; Furuta et al. 2003; Paull et al. 2000; Pilch et al. 2003; Polo and Jackson 2011; Scully and Xie 2013). In addition to $\gamma \mathrm{H} 2 \mathrm{AX}$, modification of nucleosomes by other DDR factors act to coordinate the complex signaling events of the DDR network that are involved in DNA repair of DSBs (Table 1).

Several E3 ubiquitin ligases including RNF8, RNF168, BRCA1, RNF20/40, RING1B and BMI1 are recruited to DNA lesions and ubiquitylate histones and chromatin factors to promote the DDR (Jackson and Durocher 2013; Panier and Durocher 2009). For example, phosphorylation of mediator of DNA-damage checkpoint1 (MDC1) protein by ATM recruits RNF8, which has recently been shown to ubiquitylate the linker histone $\mathrm{H} 1$ (Thorslund et al. 2015). RNF168 is recruited to damage sites through ubiquitin-dependent interactions to promote further ubiquitylation of histones by this E3 ligase, which are required to regulate DSB repair by 53BP1 and BRCA1 (Chapman and Jackson 2008; Doil et al. 2009; Panier and Durocher 2009; Polo and Jackson 2011; Stewart et al. 2009) (Fig. 1A). Interestingly, recruitment of 53BP1, which promotes NHEJ and represses $\mathrm{HR}$ through antagonizing BRCA1, relies not only on this ubiquitin-dependent 
pathway but also on histone methylation. Indeed, recognition of damaged chromatin by 53BP1 requires binding to $\mathrm{H} 4 \mathrm{~K} 20$ methylation as well as histone H2A/H2AX K15 ubiquitylation (Botuyan et al. 2006; Fradet-Turcotte et al. 2013). 53BP1 recruitment to chromatin upon DNA damage is also regulated by histone acetylation. Histones are acetylated by histone acetyltransferases (HATs) and deacetylated by histone deacetylases (HDACs). Many of these enzymes are recruited to DSBs to regulate specific acetylated residues on histones to promote either HR or NHEJ (Gong and Miller 2013). For 53BP1, acetylation of H4K16 at DSBs by the TIP60 HAT occludes the ability of the tudor domain within 53BP1 to recognize H4K20 methylation. When $\mathrm{H} 4 \mathrm{~K} 16$ is acetylated, this inhibits 53BP1 binding, which promotes BRCA1 binding and HR (Hsiao and Mizzen 2013; Tang et al. 2013). This pathway is negatively regulated by deacetylation of H4K16 by HDAC1/2. Indeed, recruitment of these HDACs to damage sites promotes 53BP1 binding and NHEJ (Miller et al. 2010; Tang et al. 2013).

In addition to 53BP1 and BRCA1 pathways, histone methylation and acetylation regulate additional pathways that participate in DSB repair. For example, transcription-associated H3K36 trimethylation (H3K36me3) by SETD2 promotes DNA repair by homologous recombination (Aymard et al. 2014; Carvalho et al. 2014; Pfister et al. 2014). Another histone PTM, H3K9 trimethylation (H3K9me3) is required for the activation of the HAT TIP60, which acetylates ATM and histone H4. ATM acetylation stimulates the kinase activity of ATM, which in turn promotes DSB repair (Sun et al. 2009). Additional work showed that de novo $\mathrm{H} 3 \mathrm{~K} 9$ trimethylation occuring at DSBs is mediated by a 
repressive protein complex containing the methyltransferase Suv39h1, KAP1 and HP1 (Ayrapetov et al. 2014). For acetylation, many readers of this mark, including proteins that contain the acetyl-lysine binding bromodomain, are recruited to DNA damage sites (Gong et al. 2015). For example, the bromodomain-containing protein ZMYND8 is recruited to DSBs in a pathway dependent on the HAT TIP60. ZMYND8 represses transcription within damaged chromatin to promote DSB repair by HR. Collectively, these examples illustrate how DDR chromatin-binding proteins and site-specific histone PTMs mediate critical signaling events that promote the sensing and repair of DSBs in mammalian cells within the chromatin environment.

Although the primary function of many histone PTMs in DSB repair signaling are well characterized, it is still unclear how writers of these marks, including Ubiquitin E3 ligases and HATs, recognize their histone substrates within the nucleosome to promote site-specific modifications of their target lysine residues (Fig. 1B). Recent studies are beginning to provide mechanistic insights into how nucleosome recognition is achieved to promote chromatin-based DDR events. Accumulating evidence suggests that key structural features of the nucleosome serve to mediate chromatin targeting by DDR factors to promote DNA damage signaling within chromatin (Chen et al. 2013; Gursoy-Yuzugullu et al. 2015b; Leung et al. 2014; Mattiroli et al. 2014; Wyrick et al. 2012). This information is starting to reveal important new ideas for how the "histone code" is encoded and read at DSB sites by DDR factors. 
In addition to histones, other non-histone chromatin factors are also modified by DDR factors. The DDR kinase ATM phosphorylates hundreds of non-histone proteins in response to DSBs, which include many target proteins that reside on chromatin (Matsuoka et al. 2007; Shiloh and Ziv 2013). As one example, the transcriptional co-repressor KAP1 is phosphorylated by ATM to promote HR (Ziv et al. 2006). Phosphorylated KAP1 leads to the decompaction of chromatin to allow DNA repair factors access to the damaged DNA. Remodeling chromatin, including by KAP1, may be particularly important in heterochromatic regions containing DSBs due to the increased packaging of the chromatin, which can act as a barrier to DSB recognition, processing and repair (Goodarzi et al. 2010; Lemaitre and Soutoglou 2014). ATM also phosphorylates MDC1 to promote the binding of E3 ubiquitin ligase RNF8, which promotes key ubiquitin signaling events at DSB sites (Huen et al. 2007; Kolas et al. 2007; Luo et al. 2011; Mailand et al. 2007).

\section{Nucleosome remodeling}

DSB induction triggers dynamic chromatin reorganization including the transition between compact and relaxed states of chromatin. Chromatin dynamics in the DDR are thought to serve many functions including to regulate transcription, reposition nucleosomes at sites of DNA damage, regulate DDR factor binding and remove chromatin obstacles to allow DNA signaling and processing at breaks including DNA end resection. Chromatin remodeling at the DSB site acts at the level of the nucleosome and is mediated by several ATP- 
dependent chromatin remodeling complexes including SWI/SNF, ISWI, NuRD and INO80. Each of these remodeling complexes have the potential to mediate ATP-dependent nucleosome dynamics in cis to regulate different aspects of the DDR (Clapier and Cairns 2009; Fyodorov and Kadonaga 2001; Price and D'andrea 2013; Smeenk and van Attikum 2013).

The SWI/SNF remodeling complex functions in the initial steps of DSB repair to promote the phosphorylation of H2AX (Park et al. 2006). The chromatin remodeling complex, INO80, regulates DSB repair by promoting the recruitment of 53BP1 and DNA end resection of DSB ends (Gospodinov et al. 2012). In mammalian cells, it has been shown that the TIP60/p400 members of the NuA4 remodeling complex catalyze the exchange of $\mathrm{H} 2 \mathrm{AZ}$ histone variant onto damaged chromatin through the removal of $\mathrm{H} 2 \mathrm{~A} / \mathrm{H} 2 \mathrm{~B}$ dimers from the nucleosome (Xu et al. 2012b; $X u$ et al. 2010). These actions are thought to create an altered chromatin structure for recruitment of DDR factors including the writer proteins that produce histone PTMs at the sites of damage to promote NHEJ repair. Moreover, H2AZ exchange is also indicated in regulating HR repair pathway as $\mathrm{H} 2 \mathrm{AZ}$ depletion results in impaired BRCA1 recruitment at DSBs (Xu et al. 2012b), although repair defects in H2AZ depleted cells were not observed in a different study (Taty-Taty et al. 2014).

The nucleosome remodeling and histone deacetylase (NuRD) complex is also recruited to DSBs to promote checkpoint activation (Smeenk et al. 2010). The recruitment of this complex to DNA damage sites requires interactions with the bromodomain-containing protein ZMYND8, which assists in silencing 
transcription at damage sites (Gong et al. 2015). Recruitment of ZMYND8 and NURD required active transcription and depletion of these factors resulted in specific defects in HR repair. Interestingly, HR-prone sites are associated with active transcription (Aymard et al. 2014). Collectively, these findings suggest a need to repress transcription at damage sites to selectively promote HR within this chromatin context. In addition, chromatin remodelers could directly interact with DDR factors to enhance their access to sites of damage. For example, $\mathrm{CHD4}$, which is the catalytic subunit of NuRD complex accumulates at DSB sites to promote RNF168 mediated ubiquitin signaling (Chou et al. 2010; Larsen et al. 2010; Polo et al. 2010; Smeenk et al. 2010). CHD4 is recruited to DSB sites in a PARP-dependent manner and controls G1/S cell-cycle transition by regulating p53 deacetylation (Chou et al. 2010; Polo et al. 2010). CHD4 recruitment to DSBs also relies on RNF8 independent of its E3 Ub ligase activity to promote chromatin decondensation at break sites (Luijsterburg et al. 2012). The ISW1 family chromatin remodelers SMARCA1 and SMARCA5 accumulate rapidly to DSBs to regulate both NHEJ and HR (Lan et al. 2010; Smeenk et al. 2013; Toiber et al. 2013; Vidi et al. 2014). Thus, chromatin remodeling complexes that are vital for transcriptional regulation are also important in promoting the DDR within chromatin. As is true for regulating sets of genes by specific remodeling complexes, it is tempting to speculate that these complexes will also show preferences for DNA damage signaling and repair functions that are dependent on the epigenomic environment of where the damage occurs. Histone modifications, chromatin structure, chromatin factor binding as well as DNA 
repair pathway choice are likely coordinated by various chromatin remodeling complexes to promote multiple functions of the DDR across diverse genome and epigenome regions.

\section{The Nucleosome}

In the mammalian genome, billions of bases of DNA are organized by chromatin into the nuclear volume of the cell. Within this environment, specific gene regulatory networks must be highly regulated to maintain cellular function and identity. Dynamic transitions from compact and inaccessible chromatin states to decompacted and accessible structures allows control of gene expression. The presence of DNA damage within these environments necessitate the use of similar chromatin dynamics to coordinate DNA damage signaling and repair. The basic unit of chromatin is the nucleosome, which forms linear arrays of DNA-protein complexes that resemble an extended "beads on a string" structure in its most relaxed state. The nucleosome core particle (NCP), the name given to the structure consisting of a core histone octamer is composed of two copies of each core histone protein $\mathrm{H} 2 \mathrm{~A}, \mathrm{H} 2 \mathrm{~B}, \mathrm{H} 3$ and $\mathrm{H} 4$ containing around 146 bp of DNA (Campos and Reinberg 2009; Davey et al. 2002; Luger et al. 1997). The NCP is the principal packaging element for DNA within the nucleus and therefore the primary determinant of DNA accessibility during fundamental cellular processes that require access to DNA within chromatin, which includes DNA damage sensing and repair. The overall sequence of histones and structure of NCPs containing the canonical histones is highly conserved from yeast to 
mammals, suggesting resistance to structural alterations, implying significant functionality for the NCP across different species (Chakravarthy et al. 2005).

The basic histone $\mathrm{N}$-terminal tails extend out from the core nucleosome structure and contain conserved lysine residues that are highly modified by PTMs. These PTMs regulate chromatin structure and function by controlling protein-nucleosome and PTM-protein interactions during chromatin-regulated processes such as transcription, replication, chromosome segregation, DNA replication and repair (Peterson and Almouzni 2013; Price and D'andrea 2013; Wang et al. 2007). Studies on DSB repair have established the critical importance of various modifications including phosphorylation, acetylation, methylation or ubiquitylation that occur on specific target residues within histones. For instance, histones $\mathrm{H} 2 \mathrm{~A}, \mathrm{H} 2 \mathrm{~B}, \mathrm{H} 4$ and histone variant $\mathrm{H} 2 \mathrm{AX}$ have been shown to be ubiquitylated at distinct lysine residues upon damage induction in order to signal and activate DSB repair (Gatti et al. 2012; Ginjala et al. 2011; Ismail et al. 2010; Mattiroli et al. 2012; Moyal et al. 2011; Nakamura et al. 2011; Yan et al. 2009) (Fig. 1B). However, a mechanistic understanding of how sitespecific epigenetic marks on these histone residues is achieved by writer enzymes and how these marks are recognized by their reader proteins within the context of the nucleosome is poorly understood. While most studies have focused on chromatin DDR factors and histone modifications involved in the DDR, very few studies have asked how these pathways are regulated at the level of the starting template, the nucleosome. While many of these proteinnucleosome interactions are mediated by histone PTMs, some regulatory 
proteins, including writers of these histone PTMs interact with specific residues, surface domains or structured regions of the nucleosome. One such structured domain is the nucleosome acidic patch present in the histone H2A-H2B dimer (Chodaparambil et al. 2007; Kalashnikova et al. 2013; McGinty and Tan 2015; Tremethick 2007). This indicates that the nucleosome does not merely act as a static packaging mechanism for DNA within cells, but rather serves as a dynamic interface for chromatin-mediated processes that regulate the chromatin landscape to orchestrate DNA damage signaling and repair within specialized chromatin surroundings.

\section{The Nucleosome Acidic Patch}

Solving the x-ray crystal structure of the NCP using reconstituted Xenopus recombinant histones revealed for the first time that in contrast to the largely basic nature of the core histones, the $\mathrm{H} 2 \mathrm{~A}-\mathrm{H} 2 \mathrm{~B}$ dimer in the NCP consists of a unique negatively charged region on the surface of the nucleosome called the acidic patch (Luger et al. 1997). A group of eight negatively charged residues constitute the acidic patch, six residues from histone H2A (E56, E61, E64, D90, E91, E92) and two from histone $\mathrm{H} 2 \mathrm{~B}$ (E102 and E110), all of which are localized on the nucleosome surface (Fig. 2A). Numerous studies suggest that the acidic patch serves as an interaction or recognition site for other chromatin proteins (Chodaparambil et al. 2007; Glatt et al. 2011; Kalashnikova et al. 2013; Wyrick et al. 2012). Although the overall structure of NCP is conserved among species, in higher eukaryotes, alternative $\mathrm{H} 2 \mathrm{~A}$ isoforms exist that can affect chromatin 
structure and stability when incorporated into NCPs and in turn regulate the chromatin-association of various factors (Bonisch and Hake 2012; Fan et al. 2002; Suto et al. 2000). With the exception of H2A.Bbd, the nucleosome acidic patch is conserved in other human $\mathrm{H} 2 \mathrm{~A}$ variants including $\mathrm{H} 2 \mathrm{AX}$, macroH2A and H2AZ (Fig. 2B). Interestingly, the acidic patch within H2AZ nucleosome is slightly extended as opposed to the other $\mathrm{H} 2 \mathrm{~A}$ and variant nucleosomes (Bonisch and Hake 2012; Chakravarthy et al. 2004; Suto et al. 2000), which may alter its functionality compared to other H2A species (discussed below).

\section{Nucleosome acidic patch and DSB repair}

Recent studies have identified the acidic patch of the nucleosome as a critical chromatin component for DSB sensing and repair. The involvement of the acidic patch in DSB repair was first identified in the Jackson and Miller labs by a systematic mutation screen for $\mathrm{H} 2 \mathrm{AX}$ that analyzed over 70 mutations in $\mathrm{H} 2 \mathrm{AX}$ and how they affected its PTMs, including phosphorylation, sumoylation and ubiquitylation (Chen et al. 2013). Surprisingly, mutations within the acidic patch of $\mathrm{H} 2 \mathrm{AX}$ or $\mathrm{H} 2 \mathrm{~A}$ abolished all detectable ubiquitylation modifications of the mutant histone protein. The functional consequences on the DDR were further studied by the reintroduction of $\mathrm{H} 2 \mathrm{AX}$ acidic patch mutants into human $\mathrm{H} 2 \mathrm{AX}$ knockout cells. Cells containing either $\mathrm{H} 2 \mathrm{AX}$ mutated within the acidic patch or lysine-less mutant, both of which result in a loss of ubiquitylation, displayed normal DDR phenotypes compared to cells reconstituted with wt $\mathrm{H} 2 \mathrm{AX}$ (Chen et al. 2013; Leung et al. 2014). Although these experiments identified the acidic 
patch as an important nucleosome feature for promoting $\mathrm{H} 2 \mathrm{AX}$ ubiquitylation, these data suggested that $\mathrm{H} 2 \mathrm{~A}$ or other $\mathrm{H} 2 \mathrm{~A}$ variants were able to compensate for the loss of H2AX ubiquitylation in the DDR. These genetic experiments however did not address whether mutations in the acidic patch directly affected the activity of E3 ligases on the NCP or if both PRC1 and RNF168 ubiquitylations that have been identified on $\mathrm{H} 2 \mathrm{~A} / \mathrm{H} 2 \mathrm{AX}$ required this nucleosome structural feature. Additional biochemical experiments identified the acidic patch on $\mathrm{H} 2 \mathrm{~A}$ and $\mathrm{H} 2 \mathrm{AX}$ as a requisite structure for RNF168 mediated ubiquitylation on lysine residue $\mathrm{K} 13 / 15$ of $\mathrm{H} 2 \mathrm{~A}$ and $\mathrm{H} 2 \mathrm{AX}$ both in cells and in vitro (Leung et al. 2014; Mattiroli et al. 2014). The interaction of RNF168 with the nucleosome was found not to be solely dependent on the acidic patch, suggesting that it might serve to orientate or promote the reaction independently from recruitment of RNF168 to chromatin (Mattiroli et al. 2014).

Several E3 ubiquitin ligases and other DDR factors promote the recruitment of RNF168 to damage sites. For example, RNF8 recruitment generates $\mathrm{K}-63$ linked ubiquitin chain on $\mathrm{H} 1$ linker histones that is recognized by RNF168 via its UDM1 module, thus recruiting RNF168 to DSBs (Thorslund et al. 2015). Once on chromatin, RNF168 ubiquitylates histones, including H2A and $\mathrm{H} 2 \mathrm{AX}$ on $\mathrm{K} 13 / 15$, which promotes the binding of the DDR factor 53BP1 to facilitate DSB repair by non-homologous end-joining (NHEJ, (Doil et al. 2009; Gatti et al. 2012; Mattiroli et al. 2012; Stewart et al. 2009). 53BP1 recruitment involves a bivalent histone modification interaction as it binds to RNF168dependent $\mathrm{H} 2 \mathrm{~A}-\mathrm{Ub}$ and $\mathrm{H} 4 \mathrm{~K} 20 \mathrm{me} 2$ through an ubiquitylation-dependent 
recruitment (UDR) motif and a methyl-binding Tudor domain respectively (FradetTurcotte et al. 2013) (Fig. 2C). RNF168 catalyzes K27 linked ubiquitin chains suggesting the involvement of these modifications in this pathway (Gatti et al. 2015). In biochemical peptide inhibition studies, the addition of a peptide derived from the acidic patch interacting portion of LANA (latency-associated nuclear antigen), a chromatin-interacting Kaposi's sarcoma-associated herpes virus (KSHV) protein that tethers the genome to host chromosomes, blocked the in vitro activity of RNF168 on H2A and H2AX (Leung et al. 2014; Mattiroli et al. 2014). These results suggested that the addition of an acidic patch interacting peptide inhibited the ability of RNF168 to target the nucleosome. These findings were also extended into cells by studying how the expression of a LANA peptide that interacts with the acidic patch affected the DDR. Expression of the acidic patch interacting fragment of LANA (amino acids 1-32) resulted in the inhibition of 53BP1 recruitment to damage sites along with a concomitant loss of $\mathrm{H} 2 \mathrm{~A}$ and H2AX K15 ubiquitylation (Leung et al. 2014). These studies identified the nucleosome acidic patch as a key nucleosome feature that is utilized by the DDR factor RNF168 to promote DNA damage signaling and repair. Furthermore, the ability to interfere with this DDR signaling pathway through the introduction of an acidic patch interacting peptide in cells further highlights the potential feasibility of targeting this nucleosome structure and the pathways reliant on it for both research and therapeutic purposes.

RING1B/BMI1 is another E3 ligase heterodimeric complex that catalyzes monoubiquitylation of $\mathrm{H} 2 \mathrm{~A}$ and $\mathrm{H} 2 \mathrm{AX}$ on the C-terminal lysines, $\mathrm{K} 118$ and $\mathrm{K} 119$ 
(de Napoles et al. 2004; Wang et al. 2004) (Fig. 2D). The RING1B/BMl1 enzyme is part of the Polycomb repressive complex1 (PRC1), that compacts chromatin to promote transcriptional repression at various gene loci (Buchwald et al. 2006; Eskeland et al. 2010; Wang et al. 2004). In the DDR, several studies have shown that RING1B/BMI1 are recruited to sites of DNA damage (Chagraoui et al. 2011; Chou et al. 2010; Facchino et al. 2010; Ginjala et al. 2011; Ismail et al. 2010). For example, BMl1 is enriched in chromatin following irradiation and copurifies with several NHEJ repair factors including Ku80, DNA-PK, PARP-1, hnRNP U (SAF-A) in glioblastoma mulltiforme brain tumor stem cells (Facchino et al. 2010). However, another study points towards its role in HR repair and maintenance of chromosome integrity in both transformed and normal human cells (Chagraoui et al. 2011). At telomeres, RING1B/BMI1 promotes fusion of dysfunctional telomeres through NHEJ. The function of the PRC1 complex in NHEJ appears to occur independently from its ability to ubiquitylate $\mathrm{H} 2 \mathrm{~A}$ as expression of a catalytic-dead RING1B is able to promote normal NHEJ of uncapped telomeres (Bartocci et al. 2014). The nucleosome acidic patch structure within $\mathrm{H} 2 \mathrm{~A}$ and $\mathrm{H} 2 \mathrm{AX}$ has also been shown to mediate the activity of the E3 ligase complex, RING1B/BMI1 (Leung et al. 2014; McGinty et al. 2014). Mutation of the acidic patch on $\mathrm{H} 2 \mathrm{~A}$ and $\mathrm{H} 2 \mathrm{AX}$ impedes ubiquitylation of K118/119 in cells (Leung et al. 2014). Importantly, using reconstituted NCPs and purified proteins acidic patch mutations also completely inhibited RING1B/BMI1 activities on nucleosome substrates in vitro (Leung et al. 2014; McGinty et al. 2014). Like RNF168, expression of the LANA peptide in cells interferes with 
these reactions resulting in reduced $\mathrm{H} 2 \mathrm{~A} / \mathrm{H} 2 \mathrm{AX}$ ubiquitylation by RING1B/BMI1.

Key mechanistic insights explaining these observations have been provided by the x-ray structure of the RING1B/BMI1-UbcH5c E3-E2 complex (the PRC1 ubiquitylation module) bound to the NCP. This enzyme-NCP co-crystal structure revealed that the basic residues of RING1B/BMI1 heterodimer interact with the histone surfaces on the NCP including amino acids within H2A-H2B acidic patch (McGinty et al. 2014). H2A-type histones residue E92 and RING1B residues K97, R98 and to a lesser extent $\mathrm{K} 93$ contribute to the RING1Bnucleosomal interface. Validation of the structural predictions through mutagenesis experiments in solution confirmed that the RING1B residue R98 inserts into the acidic pocket generated by H2A residues E61, D90 and E92; making charged hydrogen bonds with each of the amino acid side chain carboxylates within the acidic patch. Besides arginine R98, other positively charged RING1B residues also interact with the acidic patch extending the RING1B-nucleosome interaction surface. The BMI1 subunit of this E3 ubiquitin ligase heterodimer has weak nucleosome binding affinity but makes contact with the $\mathrm{H} 3 \mathrm{~N}$ '-terminal tail which is crucial for binding and proper orientation of the PRC1 complex on the nucleosomal surface (Bentley et al. 2011; McGinty and Tan 2015). Collectively, like RNF168, exposure of the nucleosome surface is necessary for RING1B/BMI1 to make contacts with the nucleosome to promote its site-specific activity on H2A histones. Unlike RNF168, how RING1B/BMI1 are targeted to DNA damage sites is unclear. While RNF168 contains Ub binding domains that recognize damage-induced ubiquitylated targets, it is unclear how 
the heterodimeric RING1B/BMI1 complex accumulates at damage sites. This question warrants further investigation as answers to this question could reveal additional mechanistic understanding of how this complex targets damaged chromatin to promote the DDR.

The use of the acidic patch to mediate DDR-dependent E3 Ub ligase activities does not seem to be limited to RNF168 and RING1B/BMI1. Another E3 Ub ligase involved in the DDR, BRCA1 (Li and Greenberg 2012) has recently been shown to ubiquitylate nucleosomal $\mathrm{H} 2 \mathrm{~A} \mathrm{~K} 127 / 129$ in an acidic patchdependent reaction (Kalb et al. 2014) (Fig. 2E). The functional significance of $\mathrm{H} 2 \mathrm{~A}$ ubiquitylation in the DDR by BRCA1 is still unclear. Previous work on mouse models of cancer has proposed that the E3 ligase activity of BRCA1 is dispensable for its tumor suppressive activity (Shakya et al. 2011). Similar to RING1B/BMI1 heterodimeric complex, the BRCA1/BARD1 forms a heterodimer to form a RING-type E3 ligase (Brzovic et al. 2001). Structural analysis and sequence alignment shows that the nucleosome-interacting region of Ring1B (including the lysine-arginine motif) and the corresponding region in BRCA1 are evolutionarily conserved. Furthermore, mutational disruption of this motif on BRCA1 or the nucleosome acidic patch eliminates H2A ubiquitylation by BRCA1 in vitro (McGinty et al. 2014). Thus, like RNF168 and Ring1B, BRCA1 appears to utilize the acidic patch on the nucleosome to promote its activity. Despite the large number of lysine residues in the nucleosome, only a select few are ubiquitylated by RNF168, RING1B/BMI1 and BRCA1 E3 ubiquitin ligases and function within DSB signaling and repair (Fig. 1B). 
It is remarkable that all of these ubiquitylation sites and their targeting enzymes require the nucleosome acidic patch. This raises an important question of how these enzymes are regulated at the level of the nucleosome to organize and promote the requisite activity at any given chromatin location without interference from a competing pathway. The nucleosome acidic patch on $\mathrm{H} 2 \mathrm{~A} / \mathrm{H} 2 \mathrm{AX}$ must therefore serve as a signaling hub that is able to accommodate and integrate a host of signals from different pathways that coordinate the chromatin activities that are essential for DSB signaling and repair (Chen et al. 2013; Gursoy-Yuzugullu et al. 2015b; Leung et al. 2014; Mattiroli et al. 2014). Although structural and biochemical studies have provided key insights into enzyme-nucleosome interactions, additional experiments in cells are necessary to better understand mechanistically how the nucleosome acidic patch interacting network is set-up and regulated. For example, many of these pathways are implicated in diseases including cancer (Becker et al. 2009; Berezovska et al. 2006; Lessard and Sauvageau 2003; Li et al. 2013). It will be interesting to know whether an imbalance of these, or other acidic patch interacting proteins, could negatively impact the function of other pathways reliant on this nucleosome surface motif. For example, cells infected with viruses or cancer cells that express high levels of acidic patch interacting proteins might impede the interactions of other factors that use the same interaction platform resulting in perturbation of these pathways. As more and more acidic patch interacting factors are identified, answers to these questions will be important to rationalize how chromatin functions to integrate these signals to promote genome stability 
and cellular homeostasis.

\section{Nucleosome Acidic Patch and Chromatin Structure in DSB Repair}

Crystal structure of the H2AZ-containing nucleosome has revealed several unique properties of this $\mathrm{H} 2 \mathrm{~A}$ variant (Suto et al. 2000). Compared to other H2Acontaining NCPs, the extended acidic patch domain of $\mathrm{H} 2 \mathrm{AZ}$ creates an altered acidic pocket on the H2AZ-nucleosomal surface. Mutational studies have shown that this can be functionally significant for DSB repair. For instance, euchromatic $\mathrm{H} 2 \mathrm{AZ}$ shows higher chromatin folding than $\mathrm{H} 2 \mathrm{~A}$ as a consequence of its extended acidic patch (Fan et al. 2004). Acetylation of histone H4 tail promotes chromatin relaxation by blocking the binding of $\mathrm{H} 4$ tail of one nucleosome to the acidic patch on the surface of an adjacent nucleosome (Chodaparambil et al. 2007; Luger et al. 1997; Robinson et al. 2008; Shogren-Knaak et al. 2006). The histone variant $\mathrm{H} 2 \mathrm{AZ}$ is transiently loaded into NCPs at DSB sites. This step is mediated by the p400 ATPase subunit of the NuA4 HAT complex in order to stabilize and maintain a compact chromatin state by increasing the interaction between the $\mathrm{H} 4$ tail and the extended acidic patch of $\mathrm{H} 2 \mathrm{AZ}$ immediately after DSB induction (Gursoy-Yuzugullu et al. 2015a; Xu et al. 2012b). The H2AZspecific histone chaperone, ANP32E (Gursoy-Yuzugullu et al. 2015a; Mao et al. 2014; Obri et al. 2014) along with the INO80 (Alatwi and Downs 2015) chromatin remodeling complex then interacts with $\mathrm{H} 2 \mathrm{AZ}$ and rapidly removes the entire $\mathrm{H} 2 \mathrm{AZ}-\mathrm{H} 2 \mathrm{~B}$ dimer, eliminating $\mathrm{H} 2 \mathrm{AZ}$ and the presence of its acidic patch from the DSB site. The removal of $\mathrm{H} 2 \mathrm{AZ}$ allows for the freeing of the $\mathrm{H} 4$ tail, a state that 
would allow accessibility and modification by another enzyme, TIP60, which acetylates $\mathrm{H} 4$. Since $\mathrm{H} 4$ acetylation blocks $\mathrm{H} 4$ tail binding to the acidic patch, the combination of $\mathrm{H} 2 \mathrm{AZ}-\mathrm{H} 2 \mathrm{~B}$ removal and $\mathrm{H} 4$ acetylation promotes switching of chromatin to a more flexible and open state to allow acetylation to facilitate DSB repair (Fig. 2F). This is validated by the observation that the acidic patch binding protein, LANA restores $\mathrm{H} 4$ acetylation in the absence of ANP32E (GursoyYuzugullu et al. 2015a). Dynamic H2AZ exchange can therefore regulate H4nucleosome interactions and modifications in several ways. The presence of $\mathrm{H} 2 \mathrm{AZ}$ is able to increase chromatin compaction by interacting more strongly with the $\mathrm{H} 4$ tail compared to other $\mathrm{H} 2 \mathrm{~A}$ species. Occlusion of the $\mathrm{H} 4$ tail within the acidic patch of $\mathrm{H} 2 \mathrm{AZ}$ should inhibit acetylation thereby promoting chromatin compaction. Removal of $\mathrm{H} 2 \mathrm{AZ}$ upon DNA damage would result in the incorporation of a different $\mathrm{H} 2 \mathrm{~A}$ species, presumably displaying reduced interactions with $\mathrm{H} 4$, which would promote $\mathrm{H} 4$ acetylation and chromatin decompaction. The histone $\mathrm{H} 2 \mathrm{~A}$ variant macroH $2 \mathrm{~A}$ is also recruited to sites of DNA damage (Timinszky et al. 2009; Xu et al. 2012a). This histone variant is responsible for compacting chromatin to promote BRCA1-retention and HR repair (Khurana et al. 2014). The potential interplay between these pathways in DSB signaling and repair is not well understood. Additional experiments studying the dynamics and kinetics of histone exchange at DSB sites and how these variants and their associated factors interact with each other to promote the DDR could help further illuminate the function of these chromatin components in the DDR. 
The regulation of chromatin-based DDR pathways is likely to be extensive with additional histone modifications and chromatin factors playing a part to finetune these chromatin reactions to promote DSB signaling and repair. Like other histones, H2AZ undergoes various posttranslational modifications, including acetylation, ubiquitylation, and sumoylation (Henikoff and Smith 2015; Weber et al. 2010). Using a novel technique called Ubiquitin-activated interaction traps (UBAITs), the Miller and Huibregtse labs identified H2AZ as a target of RNF168 (O'Connor et al. 2015) (Fig. 2G). Ubiquitylation of H2AZ by RNF168 was also shown to be dependent on the nucleosome acidic patch suggesting that RNF168 also utilizes this site on this histone variant to regulate its interactions and targeting of this substrate within the nucleosome. The role of $\mathrm{H} 2 \mathrm{AZ}$ ubiquitylation by RNF168 in the DDR is unknown. Given the altered dynamics of H2AZ upon DNA damage and its divergent amino acid sequence compared to canonical $\mathrm{H} 2 \mathrm{~A}$, it will be interesting to study the involvement of the nucleosome acidic patch and ubiquitylation on $\mathrm{H} 2 \mathrm{AZ}$ in the DDR.

\section{Nucleosome acidic patch interacting factors}

In contrast to the prominent negatively charged surfaces of the NCP, the histone tails contain many arginine and lysine residues and carry a strong net positive charge. As discussed earlier, the acidic patch domain is involved in nucleosome-nucleosome interactions via the basic histone $\mathrm{H} 4$ tail, a critical step for chromatin folding and compaction (Luger et al. 1997). In addition, the acidic patch is implicated as a crucial interaction platform for many nucleosome-protein 
complexes, some of which have been structurally demonstrated. For instance, the first complex structure of a nucleosome-peptide that was resolved and biochemically described was the viral peptide LANA from KSHV bound with the nucleosome (Barbera et al. 2006; da Silva et al. 2015; Kalashnikova et al. 2013). This pioneering work established how a viral protein interacted with the nucleosome through the acidic patch. Structural, computational modeling and experimental analyses of other nucleosome binding proteins including HMGN2, RCC1, CENP-C, Sir3, IL-33, H4-tail and the viral protein IE1 has revealed that these proteins interact with the acidic patch, which serves as the principal protein-docking region for these proteins with the nucleosome (Armache et al. 2011; Fang et al. 2016; Kato et al. 2013; Kato et al. 2011; Luger et al. 1997; Makde et al. 2010; Mucke et al. 2014) (Fig. 3).

It is intriguing that most of these proteins use a basic residue, generally an arginine or lysine, to make contact with one or more of the eight negatively charged residues that constitute the nucleosomal acidic patch (Armache et al. 2011; Chodaparambil et al. 2007; Kalashnikova et al. 2013; Kato et al. 2013; Kato et al. 2011; Makde et al. 2010; Roussel et al. 2008) (Table 2). Song Tan and colleagues recently published the co-crystal structure of the nucleosomePRC1 ubiquitylation module, which has provided a detailed mechanistic view of how the enzyme RING1B/BMl1 interacts with the acidic patch to facilitate its substrate recognition on the nucleosome (McGinty et al. 2014). All six PCGF E3s of the PRC1 and PRC2 complexes including RING1B/BMI1 recognize the H2A/H2B acidic patch (Buchwald et al. 2006; McGinty et al. 2014; Taherbhoy et 
al. 2015). Based on the identification of a host of nucleosome acidic patch interacting factors that we have reviewed here, it seems highly likely that additional proteins will be identified that rely on interactions with the nucleosome acidic patch for their function, including those involved in the DDR, on chromatin.

A key question to address in the future is how do chromatin features, including the nucleosome acidic patch, regulate specific interactions with DDR and chromatin factors in the presence of other nucleosome binding proteins that target the same acidic pocket on the nucleosome. Chromatin is also highly modified and an understanding of how additional modifications regulate interactions with chromatin factors and the nucleosome acidic patch are unknown. Another level of complexity is offered by the fact that in addition to the interactions between proteins and the nucleosome surface; negatively charged DNA also interacts electrostatically with specific basic regions of the histones and non-histone proteins in various chromatin templated processes including DNA damage signaling. For example, the RING1B/BMI1-UbcH5c E3-E2 complex forming the ubiquitin signaling module that is activated upon DSB induction is known to interact with both the nucleosomal DNA and the acidic patch of the nucleosome (McGinty et al. 2014). Given the weak interactions of many proteins with the nucleosome acidic patch, including DDR factors, these additional interactions between nucleosomal DNA and the protein could also contribute to their productive interactions with the nucleosome. The presence of multivalent interaction domains in factors such as RNF168, which contains a MIU domain to recognize ubiquitin and also interacts with the nucleosome could collectively 
modulate nucleosome interactions that allow them to write site-selective PTMs involved in the DDR to set up chromatin signals for their target proteins. Writing the histone-code involved in DSB signaling and repair thereby utilizes complex signaling events including those occurring on the surface of the nucleosome that aid in recognizing, sensing and repairing DSBs throughout the various chromatin environments that exist across the genome of mammalian cells.

\section{Nucleosome acidic patch as a therapeutic target}

Combining the above observations with the emerging paradigm that many proteins involved in DSB repair physically associate with the acidic patch to modulate chromatin dynamics, this unique chromatin interaction domain on the nucleosomal surface acts a central hub for DNA repair factor interactions with chromatin. Although cancer treatments have been "drugging" the DNA component of chromatin for over a half-century (i.e. cisplatin, ionizing radiation, (Jackson and Bartek 2009) or modifications of DNA or histones (i.e. FDAapproved inhibitors of DNA methylation or histone deacetylases) (Baylin and Jones 2011; Rodriguez and Miller 2014; Rodriguez-Paredes and Esteller 2011), no therapy currently targets the unmodified histone protein component of chromatin within the nucleosome (Cheung-Ong et al. 2013). Given the tremendous success of DNA targeting drugs as therapeutic agents in cancer, the nucleosome surface represents a potentially attractive drug target (da Silva et al. 2015; Rodriguez and Miller 2014). 
It might be feasible to develop either peptide or small molecules that interact with the nucleosome acidic patch to inhibit the binding and activity of nucleosome interacting proteins. For instance, expression of the nucleosome acidic patch interacting domain within LANA results in chromosome condensation in cells (Chodaparambil et al. 2007). The use of a similar LANA peptide fragment in cells was shown to inhibit RING1B/BMI1 and RNF168 ubiquitin ligase activity on nucleosomes (Leung et al. 2014). The inhibition of these enzymes by blocking their interactions with the nucleosome in cells led to perturbation of their DDR activities, resulting in a loss of 53BP1 binding to DSB sites with aberrant BRCA1 recruitment to damage sites in $\mathrm{G} 1$ cells, a function normally inhibited by 53BP1. Although both RING1B/BMI1 and RNF168 E3 ubiquitin ligases are involved in DDR signaling, overexpression and hyperactivation of these enzymes have been implicated in cancer initiation and development (Becker et al. 2009; Berezovska et al. 2006; Bunting et al. 2010; Lessard and Sauvageau 2003; Li et al. 2013). Supporting the potential for these pathways as therapeutic targets, small molecule inhibitors degrading or inhibiting RING1B/BMI1 ubiquitin ligase complex have been developed and show promise in anti-tumor activity in colorectal cancer models (Cao et al. 2011; Ismail et al. 2013; Kreso et al. 2014).

The wealth of available structural and biochemical information on nucleosome and nucleosome acid patch-interacting proteins can be leveraged to design, synthesize and test small molecule or peptide-derived inhibitors of nucleosome acidic patch interaction factors including RING1B/BMI1 and 
RNF168. Indeed, high-throughput screening of small molecule antagonists of the Kaposi's Sarcoma-associated Herpes virus N-terminal LANA protein binding to the nucleosome have been performed and are being developed as a means to identify compounds that could interfere with KSHV latent infection (Beauchemin et al. 2014). The development of drugs that interact with the nucleosome, including within the acidic patch, could provide powerful drug leads and research tools for understanding how chromatin factors interact with the nucleosome to modulate their biological activities that are involved in both normal and disease states. Given the large number of nucleosome acidic patch interacting factors (Fig. 3), it could prove challenging to identify drugs that target specifically one protein over others that are reliant on this nucleosome surface for chromatin binding and their function. However, therapeutic drugs that broadly target the epigenome including DNA methylation and HDAC inhibitors are used successfully in the clinic for the treatment of various cancers. Thus, development of nucleosome targeting compounds and studies testing their drug properties have the potential to identify small molecules that could deliver new avenues for therapeutic interventions.

\section{Conclusion and Perspectives}

Although the acidic patch within $\mathrm{H} 2 \mathrm{~A}-\mathrm{H} 2 \mathrm{~B}$ is the most notable interaction platform on the nucleosome, there are other potential structured regions on the nucleosome that may be of functional significance. Investigations of other structural domains on the nucleosomal surface have been performed, leading to 
novel findings that include the presence of a structured and negatively charged region adjacent to the $\mathrm{H} 2 \mathrm{~A}-\mathrm{H} 2 \mathrm{~B}$ acidic patch. This acidic pocket is composed of three residues within $\mathrm{H} 3$ and one residue from $\mathrm{H} 4$ residues (da Silva et al. 2015). In addition to the $\mathrm{H} 2 \mathrm{~A}-\mathrm{H} 2 \mathrm{~B}$ acidic patch, several residues from histone $\mathrm{H} 3$ and $\mathrm{H} 4$ tail serve as an additional association site for the BAH domain of SIR3 in yeast including residue D77 of the $\mathrm{H} 3-\mathrm{H} 4$ acidic region (Armache et al. 2011). The four residues of the $\mathrm{H} 3-\mathrm{H} 4$ acidic groove are evolutionarily conserved in human $\mathrm{H} 3$ and $\mathrm{H} 4$, making it likely that this acidic region could serve as an interaction or regulatory site for other chromatin proteins. Recent genetic screens performed in S. cerevisiae have revealed that mutations in the nucleosome acidic patch residues result in impaired recruitment of the H2B K123 Ub machinery to active genes leading to altered transcription elongation efficiency in vivo (Cucinotta et al. 2015). By analogy, it is possible that the corresponding lysine residue in human H2B i.e., H2B K120, which is ubiquitylated by RNF20/RNF40, requires the acidic patch for its catalytic activity. RNF20/RNF40 are recruited to sites of DNA damage and are involved in DSB repair (Moyal et al. 2011; Nakamura et al. 2011). It is interesting to consider how $\mathrm{H} 2 \mathrm{~A}$ and $\mathrm{H} 2 \mathrm{~B}$ ubiquitylations, which are believed to have opposing effects on chromatin structure, are coordinated at DSB sites to promote the requisite response to repair the lesion. In addition, their genetic screen to identify the key histone residues required for $\mathrm{H} 2 \mathrm{~B} \mathrm{~K} 123 \mathrm{Ub}$ recognized two other residues in the vicinity of the acidic patch, i.e. in the docking domain of $\mathrm{H} 2 \mathrm{~A}$ that influences this $\mathrm{H} 2 \mathrm{~B}$ ubiquitylation cascade (Cucinotta et al. 2015). 
Several other nucleosomal surface features/domains including the H2A docking domain, $\mathrm{H} 2 \mathrm{~B} \alpha 3-\alpha \mathrm{C}$ helices, HAR/HBR domains and the H3-H4 LRS domains exist that have been implicated as recognition modules for various regulatory proteins (Wyrick et al. 2012). Taken together, the combination of genetic screens and in vitro structural and biochemical analyses is providing additional novel insights into how diverse chromatin-associated machineries interact with the nucleosome, in addition to the nucleosome acidic patch, to promote chromatin-based DDR activities. Several topological features beyond the charged acidic pocket exists on the nucleosomal surface that control and regulate nuclear processes, which could include DNA damage signaling and repair. Future work is required to understand whether these factors are mutually exclusive or act combinatorially on the nucleosome surface to write the requisite code for the DDR within a specific chromatin context. Studies furthering our mechanistic understanding of how chromatin proteins interact with the nucleosome to promote the DDR are warranted. The nucleosome surface in combination with the presence of histone modifications and variants may play pivotal roles in coordinating the DDR within the chromatin environment. Knowledge gained from having a better understanding of chromatin-based DDR pathways can be used to improve the development and application of DNA damaging agents and epigenetic drugs for the improved treatment of human diseases.

\section{Acknowledgements}


We apologize in advance to authors we were unable to cite due to space limitations. The Miller laboratory is in part supported by the Cancer Prevention Research Institute of Texas (CPRIT, R1116). Dr. Kyle Miller is a CPRIT scholar.

\section{References}

Alatwi, H.E., and Downs, J.A. 2015. Removal of H2A.Z by INO80 promotes homologous recombination. Embo Rep 16, 986-994.

Armache, K.J., Garlick, J.D., Canzio, D., Narlikar, G.J., and Kingston, R.E. 2011. Structural basis of silencing: Sir3 BAH domain in complex with a nucleosome at 3.0 A resolution. Science 334, 977-982.

Aymard, F., Bugler, B., Schmidt, C.K., Guillou, E., Caron, P., Briois, S., lacovoni, J.S., Daburon, V., Miller, K.M., Jackson, S.P., et al. 2014. Transcriptionally active chromatin recruits homologous recombination at DNA double-strand breaks. Nature structural \& molecular biology 21, 366-U172.

Ayoub, N., Jeyasekharan, A.D., Bernal, J.A., and Venkitaraman, A.R. 2008. HP1-beta mobilization promotes chromatin changes that initiate the DNA damage response. Nature 453, 682-U614.

Ayrapetov, M.K., Gursoy-Yuzugullu, O., Xu, C., Xu, Y., and Price, B.D. 2014. DNA double-strand breaks promote methylation of histone $\mathrm{H} 3$ on lysine 9 and transient formation of repressive chromatin. Proceedings of the National Academy of Sciences of the United States of America 111, 9169-9174.

Bao, Y. 2011. Chromatin response to DNA double-strand break damage. Epigenomics 3, 307-321.

Barbera, A.J., Chodaparambil, J.V., Kelley-Clarke, B., Joukov, V., Walter, J.C., Luger, K., and Kaye, K.M. 2006. The nucleosomal surface as a docking station for Kaposi's sarcoma herpesvirus LANA. Science 311, 856-861.

Bartocci, C., Diedrich, J.K., Ouzounov, I., Li, J., Piunti, A., Pasini, D., Yates, J.R., and Denchi, E.L. 2014. Isolation of Chromatin from Dysfunctional Telomeres Reveals an Important Role for Ring1b in NHEJ-Mediated Chromosome Fusions. Cell Rep 7, 13201332.

Baylin, S.B., and Jones, P.A. 2011. A decade of exploring the cancer epigenome biological and translational implications. Nat Rev Cancer 11, 726-734. 
Beauchemin, C., Moerke, N.J., Faloon, P., and Kaye, K.M. 2014. Assay Development and High-Throughput Screening for Inhibitors of Kaposi's Sarcoma-Associated Herpesvirus N-Terminal Latency-Associated Nuclear Antigen Binding to Nucleosomes. J Biomol Screen 19, 947-958.

Beck, H.C., Nielsen, E.C., Matthiesen, R., Jensen, L.H., Sehested, M., Finn, P., Grauslund, M., Hansen, A.M., and Jensen, O.N. 2006. Quantitative proteomic analysis of post-translational modifications of human histones. Molecular \& cellular proteomics : MCP 5, 1314-1325.

Becker, M., Korn, C., Sienerth, A.R., Voswinckel, R., Luetkenhaus, K., Ceteci, F., and Rapp, U.R. 2009. Polycomb Group Protein Bmi1 Is Required for Growth of RAF Driven Non-Small-Cell Lung Cancer. PloS one 4.

Bentley, M.L., Corn, J.E., Dong, K.C., Phung, Q., Cheung, T.K., and Cochran, A.G. 2011. Recognition of $\mathrm{UbcH} 5 \mathrm{c}$ and the nucleosome by the Bmi1/Ring1b ubiquitin ligase complex. The EMBO journal 30, 3285-3297.

Berezovska, O.P., Glinskii, A.B., Yang, Z., Li, X.M., Hoffman, R.M., and Glinsky, G.V. 2006. Essential role for activation of the Polycomb group (PcG) protein chromatin silencing pathway in metastatic prostate cancer. Cell Cycle 5, 1886-1901.

Beucher, A., Birraux, J., Tchouandong, L., Barton, O., Shibata, A., Conrad, S., Goodarzi, A.A., Krempler, A., Jeggo, P.A., and Lobrich, M. 2009. ATM and Artemis promote homologous recombination of radiation-induced DNA double-strand breaks in G2. The EMBO journal 28, 3413-3427.

Bonisch, C., and Hake, S.B. 2012. Histone H2A variants in nucleosomes and chromatin: more or less stable? Nucleic acids research 40, 10719-10741.

Botuyan, M.V., Lee, J., Ward, I.M., Kim, J.E., Thompson, J.R., Chen, J., and Mer, G. 2006. Structural basis for the methylation state-specific recognition of histone H4-K2O by 53BP1 and Crb2 in DNA repair. Cell 127, 1361-1373.

Brzovic, P.S., Rajagopal, P., Hoyt, D.W., King, M.C., and Klevit, R.E. 2001. Structure of a BRCA1-BARD1 heterodimeric RING-RING complex. Nature structural biology 8, 833837.

Buchwald, G., van der Stoop, P., Weichenrieder, O., Perrakis, A., van Lohuizen, M., and Sixma, T.K. 2006. Structure and E3-ligase activity of the Ring-Ring complex of polycomb proteins Bmi1 and Ring1b. Embo Journal 25, 2465-2474.

Bunting, S.F., Callen, E., Wong, N., Chen, H.T., Polato, F., Gunn, A., Bothmer, A., Feldhahn, N., Fernandez-Capetillo, O., Cao, L., et al. 2010. 53BP1 inhibits homologous 
recombination in Brca1-deficient cells by blocking resection of DNA breaks. Cell 141, 243-254.

Burma, S., Chen, B.P., Murphy, M., Kurimasa, A., and Chen, D.J. 2001. ATM phosphorylates histone $\mathrm{H} 2 \mathrm{AX}$ in response to DNA double-strand breaks. Journal of Biological Chemistry 276, 42462-42467.

Campos, E.I., and Reinberg, D. 2009. Histones: annotating chromatin. Annual review of genetics 43, 559-599.

Cao, L.X., Bombard, J., Cintron, K., Sheedy, J., Weetall, M.L., and Davis, T.W. 2011. BMI1 As a Novel Target for Drug Discovery in Cancer. Journal of cellular biochemistry 112, 2729-2741.

Carvalho, S., Vitor, A.C., Sridhara, S.C., Martins, F.B., Raposo, A.C., Desterro, J.M.P., Ferreira, J., and de Almeida, S.F. 2014. SETD2 is required for DNA double-strand break repair and activation of the p53-mediated checkpoint. Elife 3.

Celeste, A., Petersen, S., Romanienko, P.J., Fernandez-Capetillo, O., Chen, H.T., Sedelnikova, O.A., Reina-San-Martin, B., Coppola, V., Meffre, E., Difilippantonio, M.J., et al. 2002. Genomic instability in mice lacking histone H2AX. Science 296, 922-927.

Chagraoui, J., Hebert, J., Girard, S., and Sauvageau, G. 2011. An anticlastogenic function for the Polycomb Group gene Bmi1. Proceedings of the National Academy of Sciences of the United States of America 108, 5284-5289.

Chailleux, C., Tyteca, S., Papin, C., Boudsocq, F., Puget, N., Courilleau, C., Grigoriev, M., Canitrot, Y., and Trouche, D. 2010. Physical interaction between the histone acetyl transferase Tip60 and the DNA double-strand breaks sensor MRN complex. Biochemical Journal 426, 365-371.

Chakravarthy, S., Bao, Y., Roberts, V.A., Tremethick, D., and Luger, K. 2004. Structural characterization of histone $\mathrm{H} 2 \mathrm{~A}$ variants. Cold Spring Harbor symposia on quantitative biology 69, 227-234.

Chakravarthy, S., Park, Y.J., Chodaparambil, J., Edayathumangalam, R.S., and Luger, K. 2005. Structure and dynamic properties of nucleosome core particles. FEBS letters 579, 895-898.

Chapman, J.R., and Jackson, S.P. 2008. Phospho-dependent interactions between NBS1 and MDC1 mediate chromatin retention of the MRN complex at sites of DNA damage. Embo Rep 9, 795-801. 
Chen, W.T., Alpert, A., Leiter, C., Gong, F., Jackson, S.P., and Miller, K.M. 2013. Systematic identification of functional residues in mammalian histone H2AX. Molecular and cellular biology 33, 111-126.

Cheung-Ong, K., Giaever, G., and Nislow, C. 2013. DNA-damaging agents in cancer chemotherapy: serendipity and chemical biology. Chemistry \& biology 20, 648-659.

Chodaparambil, J.V., Barbera, A.J., Lu, X., Kaye, K.M., Hansen, J.C., and Luger, K. 2007. A charged and contoured surface on the nucleosome regulates chromatin compaction. Nature structural \& molecular biology 14, 1105-1107.

Chou, D.M., Adamson, B., Dephoure, N.E., Tan, X., Nottke, A.C., Hurov, K.E., Gygi, S.P., Colaiacovo, M.P., and Elledge, S.J. 2010. A chromatin localization screen reveals poly ADP ribose-regulated recruitment of the repressive polycomb and NuRD complexes to sites of DNA damage. Proceedings of the National Academy of Sciences of the United States of America 107, 18475-18480.

Ciccia, A., and Elledge, S.J. 2010. The DNA damage response: making it safe to play with knives. Mol Cell 40, 179-204.

Clapier, C.R., and Cairns, B.R. 2009. The biology of chromatin remodeling complexes. Annual review of biochemistry 78, 273-304.

Cucinotta, C.E., Young, A.N., Klucevsek, K.M., and Arndt, K.M. 2015. The Nucleosome Acidic Patch Regulates the H2B K123 Monoubiquitylation Cascade and Transcription Elongation in Saccharomyces cerevisiae. PLoS genetics 11, e1005420.

da Silva, I.T.G., de Oliveira, P.S.L., and Santos, G.M. 2015. Featurring the nucleosome surface as a therapeutic target. Trends Pharmacol Sci 36, 263-269.

Davey, C.A., Sargent, D.F., Luger, K., Maeder, A.W., and Richmond, T.J. 2002. Solvent mediated interactions in the structure of the nucleosome core particle at 1.9 angstrom resolution. Journal of molecular biology 319, 1097-1113.

de Napoles, M., Mermoud, J.E., Wakao, R., Tang, Y.A., Endoh, M., Appanah, R., Nesterova, T.B., Silva, J., Otte, A.P., Vidal, M., et al. 2004. Polycomb group proteins Ring1A/B link ubiquitylation of histone $\mathrm{H} 2 \mathrm{~A}$ to heritable gene silencing and $X$ inactivation. Dev Cell 7, 663-676.

Doil, C., Mailand, N., Bekker-Jensen, S., Menard, P., Larsen, D.H., Pepperkok, R., Ellenberg, J., Panier, S., Durocher, D., Bartek, J., et al. 2009. RNF168 binds and amplifies ubiquitin conjugates on damaged chromosomes to allow accumulation of repair proteins. Cell 136, 435-446. 
Eskeland, R., Leeb, M., Grimes, G.R., Kress, C., Boyle, S., Sproul, D., Gilbert, N., Fan, Y.H., Skoultchi, A.I., Wutz, A., et al. 2010. Ring1B Compacts Chromatin Structure and Represses Gene Expression Independent of Histone Ubiquitination. Mol Cell 38, 452464.

Facchino, S., Abdouh, M., Chatoo, W., and Bernier, G. 2010. BMl1 confers radioresistance to normal and cancerous neural stem cells through recruitment of the DNA damage response machinery. The Journal of neuroscience : the official journal of the Society for Neuroscience 30, 10096-10111.

Fan, J.Y., Gordon, F., Luger, K., Hansen, J.C., and Tremethick, D.J. 2002. The essential histone variant H2A.Z regulates the equilibrium between different chromatin conformational states. Nature structural biology 9, 172-176.

Fan, J.Y., Rangasamy, D., Luger, K., and Tremethick, D.J. 2004. H2A.Z alters the nucleosome surface to promote HP1alpha-mediated chromatin fiber folding. Mol Cell 16, 655-661.

Fang, Q., Chen, P., Wang, M., Fang, J., Yang, N., Li, G., and Xu, R.M. 2016. Human cytomegalovirus IE1 protein alters the higher-order chromatin structure by targeting the acidic patch of the nucleosome. Elife 5 .

Fernandez-Capetillo, O., Allis, C.D., and Nussenzweig, A. 2004. Phosphorylation of histone H2B at DNA double-strand breaks. J Exp Med 199, 1671-1677.

Fernandez-Capetillo, O., Celeste, A., and Nussenzweig, A. 2003. Focusing on foci: $\mathrm{H} 2 \mathrm{AX}$ and the recruitment of DNA-damage response factors. Cell Cycle 2, 426-427.

Fernandez-Capetillo, O., Chen, H.T., Celeste, A., Ward, I., Romanienko, P.J., Morales, J.C., Naka, K., Xia, Z., Camerini-Otero, R.D., Motoyama, N., et al. 2002. DNA damageinduced G2-M checkpoint activation by histone H2AX and 53BP1. Nature cell biology 4, 993-997.

Fnu, S., Williamson, E.A., De Haro, L.P., Brenneman, M., Wray, J., Shaheen, M., Radhakrishnan, K., Lee, S.H., Nickoloff, J.A., and Hromas, R. 2011. Methylation of histone H3 lysine 36 enhances DNA repair by nonhomologous end-joining. Proceedings of the National Academy of Sciences of the United States of America 108, 540-545.

Fradet-Turcotte, A., Canny, M.D., Escribano-Diaz, C., Orthwein, A., Leung, C.C., Huang, H., Landry, M.C., Kitevski-LeBlanc, J., Noordermeer, S.M., Sicheri, F., et al. 2013. 53BP1 is a reader of the DNA-damage-induced H2A Lys 15 ubiquitin mark. Nature 499, 50-54. 
Furuta, T., Takemura, H., Liao, Z.Y., Aune, G.J., Redon, C., Sedelnikova, O.A., Pilch, D.R., Rogakou, E.P., Celeste, A., Chen, H.T., et al. 2003. Phosphorylation of histone $\mathrm{H} 2 \mathrm{AX}$ and activation of Mre11, Rad50, and Nbs1 in response to replication-dependent DNA double-strand breaks induced by mammalian DNA topoisomerase I cleavage complexes. The Journal of biological chemistry 278, 20303-20312.

Fyodorov, D.V., and Kadonaga, J.T. 2001. The many faces of chromatin remodeling: SWltching beyond transcription. Cell 106, 523-525.

Gatti, M., Pinato, S., Maiolica, A., Rocchio, F., Prato, M.G., Aebersold, R., and Penengo, L. 2015. RNF168 promotes noncanonical K27 ubiquitination to signal DNA damage. Cell Rep 10, 226-238.

Gatti, M., Pinato, S., Maspero, E., Soffientini, P., Polo, S., and Penengo, L. 2012. A novel ubiquitin mark at the $\mathrm{N}$-terminal tail of histone H2As targeted by RNF168 ubiquitin ligase. Cell Cycle 11, 2538-2544.

Ginjala, V., Nacerddine, K., Kulkarni, A., Oza, J., Hill, S.J., Yao, M., Citterio, E., van Lohuizen, M., and Ganesan, S. 2011. BMI1 is recruited to DNA breaks and contributes to DNA damage-induced H2A ubiquitination and repair. Molecular and cellular biology 31, $1972-1982$.

Glatt, S., Alfieri, C., and Muller, C.W. 2011. Recognizing and remodeling the nucleosome. Current opinion in structural biology 21, 335-341.

Gong, F.D., Chiu, L.Y., Cox, B., Aymard, F., Clouaire, T., Leung, J.W., Cammarata, M., Perez, M., Agarwal, P., Brodbelt, J.S., et al. 2015. Screen identifies bromodomain protein ZMYND8 in chromatin recognition of transcription-associated DNA damage that promotes homologous recombination. Genes \& development 29, 197-211.

Gong, F.D., and Miller, K.M. 2013. Mammalian DNA repair: HATs and HDACs make their mark through histone acetylation. Mutat Res-Fund Mol M 750, 23-30.

Goodarzi, A.A., Jeggo, P., and Lobrich, M. 2010. The influence of heterochromatin on DNA double strand break repair: Getting the strong, silent type to relax. DNA repair 9, 1273-1282.

Gospodinov, A., Vaissiere, T., Krastev, D.B., Legube, G., Anachkova, B., and Herceg, Z. 2012. Mammalian Ino80 Mediates Double-Strand Break Repair through Its Role in DNA End Strand Resection (vol 31, pg 4735, 2011. Molecular and cellular biology 32, 10301030. 
Gupta, A., Sharma, G.G., Young, C.S., Agarwal, M., Smith, E.R., Paull, T.T., Lucchesi, J.C., Khanna, K.K., Ludwig, T., and Pandita, T.K. 2005. Involvement of human MOF in ATM function. Molecular and cellular biology 25, 5292-5305.

Gursoy-Yuzugullu, O., Ayrapetov, M.K., and Price, B.D. 2015a. Histone chaperone Anp32e removes H2A.Z from DNA double-strand breaks and promotes nucleosome reorganization and DNA repair. Proceedings of the National Academy of Sciences of the United States of America 112, 7507-7512.

Gursoy-Yuzugullu, O., House, N., and Price, B.D. 2015b. Patching Broken DNA: Nucleosome Dynamics and the Repair of DNA Breaks. Journal of molecular biology.

Hartlerode, A.J., Guan, Y., Rajendran, A., Ura, K., Schotta, G., Xie, A., Shah, J.V., and Scully, R. 2012. Impact of histone H4 lysine 20 methylation on 53BP1 responses to chromosomal double strand breaks. PloS one 7, e49211.

Henikoff, S., and Smith, M.M. 2015. Histone variants and epigenetics. Cold Spring Harbor perspectives in biology 7, a019364.

Hsiao, K.Y., and Mizzen, C.A. 2013. Histone H4 deacetylation facilitates 53BP1 DNA damage signaling and double-strand break repair. J Mol Cell Biol 5, 157-165.

Huen, M.S., Grant, R., Manke, I., Minn, K., Yu, X., Yaffe, M.B., and Chen, J. 2007. RNF8 transduces the DNA-damage signal via histone ubiquitylation and checkpoint protein assembly. Cell 131, 901-914.

Huertas, P. 2010. DNA resection in eukaryotes: deciding how to fix the break. Nature structural \& molecular biology 17, 11-16.

Huyen, Y., Zgheib, O., Ditullio, R.A., Jr., Gorgoulis, V.G., Zacharatos, P., Petty, T.J., Sheston, E.A., Mellert, H.S., Stavridi, E.S., and Halazonetis, T.D. 2004. Methylated lysine 79 of histone H3 targets 53BP1 to DNA double-strand breaks. Nature 432, 406411.

Ikura, T., Tashiro, S., Kakino, A., Shima, H., Jacob, N., Amunugarna, R., Yoder, K., Izumi, S., Kuraoka, I., Tanaka, K., et al. 2007. DNA damage-dependent acetylation and ubiquitination of H2AX enhances chromatin dynamics. Molecular and cellular biology 27 , 7028-7040.

Ismail, I.H., Andrin, C., McDonald, D., and Hendzel, M.J. 2010. BMI1-mediated histone ubiquitylation promotes DNA double-strand break repair. Journal of Cell Biology 191, 4560. 
Ismail, I.H., McDonald, D., Strickfaden, H., Xu, Z.Z., and Hendzel, M.J. 2013. A Small Molecule Inhibitor of Polycomb Repressive Complex 1 Inhibits Ubiquitin Signaling at DNA Double-strand Breaks. Journal of Biological Chemistry 288, 26944-26954.

Jackson, S.P., and Bartek, J. 2009. The DNA-damage response in human biology and disease. Nature 461, 1071-1078.

Jackson, S.P., and Durocher, D. 2013. Regulation of DNA damage responses by ubiquitin and SUMO. Mol Cell 49, 795-807.

Jiang, X.F., Xu, Y., and Price, B.D. 2010. Acetylation of H2AX on lysine 36 plays a key role in the DNA double-strand break repair pathway. FEBS letters 584, 2926-2930.

Kalashnikova, A.A., Porter-Goff, M.E., Muthurajan, U.M., Luger, K., and Hansen, J.C. 2013. The role of the nucleosome acidic patch in modulating higher order chromatin structure. Journal of the Royal Society, Interface / the Royal Society 10, 20121022.

Kalb, R., Mallery, D.L., Larkin, C., Huang, J.T.J., and Hiom, K. 2014. BRCA1 Is a Histone-H2A-Specific Ubiquitin Ligase. Cell Rep 8, 999-1005.

Kato, H., Jiang, J., Zhou, B.R., Rozendaal, M., Feng, H., Ghirlando, R., Xiao, T.S., Straight, A.F., and Bai, Y. 2013. A conserved mechanism for centromeric nucleosome recognition by centromere protein CENP-C. Science 340, 1110-1113.

Kato, H., van Ingen, H., Zhou, B.R., Feng, H., Bustin, M., Kay, L.E., and Bai, Y. 2011. Architecture of the high mobility group nucleosomal protein 2-nucleosome complex as revealed by methyl-based NMR. Proceedings of the National Academy of Sciences of the United States of America 108, 12283-12288.

Khurana, S., Kruhlak, M.J., Kim, J., Tran, A.D., Liu, J., Nyswaner, K., Shi, L., Jailwala, P., Sung, M.H., Hakim, O., et al. 2014. A macrohistone variant links dynamic chromatin compaction to BRCA1-dependent genome maintenance. Cell Rep 8, 1049-1062.

Kim, Y.C., Gerlitz, G., Furusawa, T., Catez, F., Nussenzweig, A., Oh, K.S., Kraemer, K.H., Shiloh, Y., and Bustin, M. 2009. Activation of ATM depends on chromatin interactions occurring before induction of DNA damage. Nature cell biology 11, 92-U192. Kolas, N.K., Chapman, J.R., Nakada, S., Ylanko, J., Chahwan, R., Sweeney, F.D., Panier, S., Mendez, M., Wildenhain, J., Thomson, T.M., et al. 2007. Orchestration of the DNA-damage response by the RNF8 ubiquitin ligase. Science 318, 1637-1640.

Kouzarides, T. 2007. Chromatin modifications and their function. Cell 128, 693-705.

Kreso, A., van Galen, P., Pedley, N.M., Lima-Fernandes, E., Frelin, C., Davis, T., Cao, L.X., Baiazitov, R., Du, W., Sydorenko, N., et al. 2014. Self-renewal as a therapeutic target in human colorectal cancer. Nat Med 20, 29-+. 
Lan, L., Ui, A., Nakajima, S., Hatakeyama, K., Hoshi, M., Watanabe, R., Janicki, S.M., Ogiwara, H., Kohno, T., Kanno, S., et al. 2010. The ACF1 Complex Is Required for DNA Double-Strand Break Repair in Human Cells. Mol Cell 40, 976-987.

Larsen, D.H., Poinsignon, C., Gudjonsson, T., Dinant, C., Payne, M.R., Hari, F.J., Danielsen, J.M.R., Menard, P., Sand, J.C., Stucki, M., et al. 2010. The chromatinremodeling factor CHD4 coordinates signaling and repair after DNA damage. Journal of Cell Biology 190, 731-740.

Lee, H.S., Park, J.H., Kim, S.J., Kwon, S.J., and Kwon, J. 2010. A cooperative activation loop among SWI/SNF, gamma-H2AX and H3 acetylation for DNA double-strand break repair. Embo Journal 29, 1434-1445.

Lemaitre, C., and Soutoglou, E. 2014. Double strand break (DSB) repair in heterochromatin and heterochromatin proteins in DSB repair. DNA repair 19, 163-168.

Lessard, J., and Sauvageau, G. 2003. Bmi-1 determines the proliferative capacity of normal and leukaemic stem cells. Nature 423, 255-260.

Leung, J.W., Agarwal, P., Canny, M.D., Gong, F., Robison, A.D., Finkelstein, I.J., Durocher, D., and Miller, K.M. 2014. Nucleosome acidic patch promotes RNF168- and RING1B/BMI1-dependent $\mathrm{H} 2 \mathrm{AX}$ and $\mathrm{H} 2 \mathrm{~A}$ ubiquitination and DNA damage signaling.v PLoS genetics 10, e1004178.

Li, M.L., and Greenberg, R.A. 2012. Links between genome integrity and BRCA1 tumor suppression. Trends in biochemical sciences 37, 418-424.

Li, X., Corsa, C.A., Pan, P.W., Wu, L., Ferguson, D., Yu, X., Min, J., and Dou, Y. 2010. MOF and $\mathrm{H} 4 \mathrm{~K} 16$ acetylation play important roles in DNA damage repair by modulating recruitment of DNA damage repair protein Mdc1. Molecular and cellular biology 30, 5335-5347.

Li, X., Yang, Z., Song, W., Zhou, L., Li, Q., Tao, K., Zhou, J., Wang, X., Zheng, Z., You, N., et al. 2013. Overexpression of Bmi-1 contributes to the invasion and metastasis of hepatocellular carcinoma by increasing the expression of matrix metalloproteinase (MMP)2, MMP-9 and vascular endothelial growth factor via the PTEN/PI3K/Akt pathway. International journal of oncology 43, 793-802.

Lieber, M.R. 2010. The mechanism of double-strand DNA break repair by the nonhomologous DNA end-joining pathway. Annual review of biochemistry 79, 181-211.

Luger, K., Mader, A.W., Richmond, R.K., Sargent, D.F., and Richmond, T.J. 1997. Crystal structure of the nucleosome core particle at 2.8 angstrom resolution. Nature 389 , 251-260. 
Luijsterburg, M.S., Acs, K., Ackermann, L., Wiegant, W.W., Bekker-Jensen, S., Larsen, D.H., Khanna, K.K., van Attikum, H., Mailand, N., and Dantuma, N.P. 2012. A new noncatalytic role for ubiquitin ligase RNF8 in unfolding higher-order chromatin structure. Embo Journal 31, 2511-2527.

Luijsterburg, M.S., and van Attikum, H. 2011. Chromatin and the DNA damage response: the cancer connection. Molecular oncology 5, 349-367.

Lukas, C., Melander, F., Stucki, M., Falck, J., Bekker-Jensen, S., Goldberg, M., Lerenthal, Y., Jackson, S.P., Bartek, J., and Lukas, J. 2004. Mdc1 couples DNA doublestrand break recognition by Nbs1 with its $\mathrm{H} 2 \mathrm{AX}$-dependent chromatin retention. The EMBO journal 23, 2674-2683.

Luo, K.T., Yuan, J., and Lou, Z.K. 2011. Oligomerization of MDC1 Protein Is Important for Proper DNA Damage Response. Journal of Biological Chemistry 286, 28192-28199.

Ma, T., Chen, Y.B., Zhang, F., Yang, C.Y., Wang, S.M., and Yu, X.C. 2013. RNF111Dependent Neddylation Activates DNA Damage-Induced Ubiquitination. Mol Cell 49, 897-907.

Mailand, N., Bekker-Jensen, S., Faustrup, H., Melander, F., Bartek, J., Lukas, C., and Lukas, J. 2007. RNF8 ubiquitylates histones at DNA double-strand breaks and promotes assembly of repair proteins. Cell 131, 887-900.

Makde, R.D., England, J.R., Yennawar, H.P., and Tan, S. 2010. Structure of RCC1 chromatin factor bound to the nucleosome core particle. Nature 467, 562-566.

Mao, Z., Pan, L., Wang, W.X., Sun, J., Shan, S., Dong, Q., Liang, X.P., Dai, L.C., Ding, X.J., Chen, S., et al. 2014. Anp32e, a higher eukaryotic histone chaperone directs preferential recognition for H2A.Z. Cell Res 24, 389-399.

Matsuoka, S., Ballif, B.A., Smogorzewska, A., McDonald, E.R., 3rd, Hurov, K.E., Luo, J., Bakalarski, C.E., Zhao, Z., Solimini, N., Lerenthal, Y., et al. 2007. ATM and ATR substrate analysis reveals extensive protein networks responsive to DNA damage. Science 316, 1160-1166.

Mattiroli, F., Uckelmann, M., Sahtoe, D.D., van Dijk, W.J., and Sixma, T.K. 2014. The nucleosome acidic patch plays a critical role in RNF168-dependent ubiquitination of histone H2A. Nature communications 5, 3291.

Mattiroli, F., Vissers, J.H., van Dijk, W.J., Ikpa, P., Citterio, E., Vermeulen, W., Marteijn, J.A., and Sixma, T.K. 2012. RNF168 ubiquitinates K13-15 on H2A/H2AX to drive DNA damage signaling. Cell 150, 1182-1195. 
McGinty, R.K., Henrici, R.C., and Tan, S. 2014. Crystal structure of the PRC1 ubiquitylation module bound to the nucleosome. Nature 514, 591-596.

McGinty, R.K., and Tan, S. 2015. Nucleosome structure and function. Chemical reviews 115, 2255-2273.

Miller, K.M., and Jackson, S.P. 2012. Histone marks: repairing DNA breaks within the context of chromatin. Biochemical Society transactions 40, 370-376.

Miller, K.M., Tjeertes, J.V., Coates, J., Legube, G., Polo, S.E., Britton, S., and Jackson, S.P. 2010. Human HDAC1 and HDAC2 function in the DNA-damage response to promote DNA nonhomologous end-joining. Nature structural \& molecular biology 17, 1144-1151.

Misteli, T., and Soutoglou, E. 2009. The emerging role of nuclear architecture in DNA repair and genome maintenance. Nat Rev Mol Cell Bio 10, 243-254.

Moyal, L., Lerenthal, Y., Gana-Weisz, M., Mass, G., So, S., Wang, S.Y., Eppink, B., Chung, Y.M., Shalev, G., Shema, E., et al. 2011. Requirement of ATM-dependent monoubiquitylation of histone $\mathrm{H} 2 \mathrm{~B}$ for timely repair of DNA double-strand breaks. Mol Cell $41,529-542$.

Mucke, K., Paulus, C., Bernhardt, K., Gerrer, K., Schon, K., Fink, A., Sauer, E.M., Asbach-Nitzsche, A., Harwardt, T., Kieninger, B., et al. 2014. Human cytomegalovirus major immediate early 1 protein targets host chromosomes by docking to the acidic pocket on the nucleosome surface. Journal of virology 88, 1228-1248.

Musselman, C.A., Lalonde, M.E., Cote, J., and Kutateladze, T.G. 2012. Perceiving the epigenetic landscape through histone readers. Nature structural \& molecular biology 19 , 1218-1227.

Nakamura, K., Kato, A., Kobayashi, J., Yanagihara, H., Sakamoto, S., Oliveira, D.V., Shimada, M., Tauchi, H., Suzuki, H., Tashiro, S., et al. 2011. Regulation of homologous recombination by RNF20-dependent H2B ubiquitination. Mol Cell 41, 515-528.

O'Connor, H.F., Lyon, N., Leung, J.W., Agarwal, P., Swaim, C.D., Miller, K.M., and Huibregtse, J.M. 2015. Ubiquitin-Activated Interaction Traps (UBAITs) identify E3 ligase binding partners. Embo Rep 16, 1699-1712.

Obri, A., Ouararhni, K., Papin, C., Diebold, M.L., Padmanabhan, K., Marek, M., Stoll, I., Roy, L., Reilly, P.T., Mak, T.W., et al. 2014. ANP32E is a histone chaperone that removes H2A.Z from chromatin. Nature 505, 648-+.

Oda, H., Hubner, M.R., Beck, D.B., Vermeulen, M., Hurwitz, J., Spector, D.L., and Reinberg, D. 2010. Regulation of the Histone H4 Monomethylase PR-Set7 by 
CRL4(cdt2)-Mediated PCNA-Dependent Degradation during DNA Damage. Mol Cell 40, 364-376.

Ogiwara, H., Ui, A., Otsuka, A., Satoh, H., Yokomi, I., Nakajima, S., Yasui, A., Yokota, J., and Kohno, T. 2011. Histone acetylation by CBP and p300 at double-strand break sites facilitates SWI/SNF chromatin remodeling and the recruitment of non-homologous end joining factors. Oncogene 30, 2135-2146.

Panier, S., and Durocher, D. 2009. Regulatory ubiquitylation in response to DNA doublestrand breaks. DNA repair 8, 436-443.

Park, J.H., Park, E.J., Lee, H.S., Kim, S.J., Hur, S.K., Imbalzano, A.N., and Kwon, J. 2006. Mammalian SWI/SNF complexes facilitate DNA double-strand break repair by promoting gamma-H2AX induction. The EMBO journal 25, 3986-3997.

Paull, T.T., Rogakou, E.P., Yamazaki, V., Kirchgessner, C.U., Gellert, M., and Bonner, W.M. 2000. A critical role for histone $H 2 A X$ in recruitment of repair factors to nuclear foci after DNA damage. Current biology : CB 10, 886-895.

Peterson, C.L., and Almouzni, G. 2013. Nucleosome Dynamics as Modular Systems that Integrate DNA Damage and Repair. Cold Spring Harbor perspectives in biology 5.

Pfister, S.X., Ahrabi, S., Zalmas, L.P., Sarkar, S., Aymard, F., Bachrati, C.Z., Helleday, T., Legube, G., La Thangue, N.B., Porter, A.C.G., et al. 2014. SETD2-Dependent Histone H3K36 Trimethylation Is Required for Homologous Recombination Repair and Genome Stability. Cell Rep 7, 2006-2018.

Pilch, D.R., Sedelnikova, O.A., Redon, C., Celeste, A., Nussenzweig, A., and Bonner, W.M. 2003. Characteristics of gamma-H2AX foci at DNA double strand breaks sites. Biochemistry and Cell Biology-Biochimie Et Biologie Cellulaire 81, 123-129.

Polo, S.E., and Jackson, S.P. 2011. Dynamics of DNA damage response proteins at DNA breaks: a focus on protein modifications. Genes \& development 25, 409-433.

Polo, S.E., Kaidi, A., Baskcomb, L., Galanty, Y., and Jackson, S.P. 2010. Regulation of DNA-damage responses and cell-cycle progression by the chromatin remodelling factor CHD4. Embo Journal 29, 3130-3139.

Price, B.D., and D'andrea, A.D. 2013. Chromatin Remodeling at DNA Double-Strand Breaks. Cell 152, 1344-1354.

Robinson, P.J.J., An, W., Routh, A., Martino, F., Chapman, L., Roeder, R.G., and Rhodes, D. 2008. $30 \mathrm{~nm}$ chromatin fibre decompaction requires both H4-K16 acetylation and linker histone eviction. Journal of molecular biology $381,816-825$. 
Rodriguez, R., and Miller, K.M. 2014. Unravelling the genomic targets of small molecules using high-throughput sequencing. Nat Rev Genet 15, 783-796.

Rodriguez-Paredes, M., and Esteller, M. 2011. Cancer epigenetics reaches mainstream oncology. Nat Med 17, 330-339.

Rogakou, E.P., Boon, C., Redon, C., and Bonner, W.M. 1999. Megabase chromatin domains involved in DNA double-strand breaks in vivo. The Journal of cell biology 146, 905-916.

Rogakou, E.P., Pilch, D.R., Orr, A.H., Ivanova, V.S., and Bonner, W.M. 1998. DNA double-stranded breaks induce histone H2AX phosphorylation on serine 139. The Journal of biological chemistry $273,5858-5868$.

Rossetto, D., Truman, A.W., Kron, S.J., and Cote, J. 2010. Epigenetic modifications in double-strand break DNA damage signaling and repair. Clinical cancer research : an official journal of the American Association for Cancer Research 16, 4543-4552.

Roussel, L., Erard, M., Cayrol, C., and Girard, J.P. 2008. Molecular mimicry between IL33 and KSHV for attachment to chromatin through the H2A-H2B acidic pocket. Embo Rep 9, 1006-1012.

Ruthenburg, A.J., Li, H., Patel, D.J., and Allis, C.D. 2007. Multivalent engagement of chromatin modifications by linked binding modules. Nature reviews. Molecular cell biology 8, 983-994.

San Filippo, J., Sung, P., and Klein, H. 2008. Mechanism of eukaryotic homologous recombination. Annual review of biochemistry 77, 229-257.

Savic, V., Yin, B., Maas, N.L., Bredemeyer, A.L., Carpenter, A.C., Helmink, B.A., YangLott, K.S., Sleckman, B.P., and Bassing, C.H. 2009. Formation of Dynamic gammaH2AX Domains along Broken DNA Strands Is Distinctly Regulated by ATM and MDC1 and Dependent upon H2AX Densities in Chromatin. Mol Cell 34, 298-310.

Scully, R., and Xie, A. 2013. Double strand break repair functions of histone H2AX. Mutation research 750, 5-14.

Sedelnikova, O.A., Rogakou, E.P., Panyutin, I.G., and Bonner, W.M. 2002. Quantitative detection of (125)IdU-induced DNA double-strand breaks with gamma-H2AX antibody. Radiation research 158, 486-492.

Seeber, A., Hauer, M., and Gasser, S.M. 2013. Nucleosome remodelers in doublestrand break repair. Current opinion in genetics \& development 23, 174-184. 
Shakya, R., Reid, L.J., Reczek, C.R., Cole, F., Egli, D., Lin, C.S., deRooij, D.G., Hirsch, S., Ravi, K., Hicks, J.B., et al. 2011. BRCA1 Tumor Suppression Depends on BRCT Phosphoprotein Binding, But Not Its E3 Ligase Activity. Science 334, 525-528.

Sharma, G.G., So, S., Gupta, A., Kumar, R., Cayrou, C., Avvakumov, N., Bhadra, U., Pandita, R.K., Porteus, M.H., Chen, D.J., et al. 2010. MOF and Histone H4 Acetylation at Lysine 16 Are Critical for DNA Damage Response and Double-Strand Break Repair. Molecular and cellular biology 30, 3582-3595.

Shiloh, Y., and Ziv, Y. 2013. The ATM protein kinase: regulating the cellular response to genotoxic stress, and more. Nature reviews. Molecular cell biology 14, 197-210.

Shogren-Knaak, M., Ishii, H., Sun, J.M., Pazin, M.J., Davie, J.R., and Peterson, C.L. 2006. Histone H4-K16 acetylation controls chromatin structure and protein interactions. Science 311, 844-847.

Smeenk, G., and van Attikum, H. 2013. The chromatin response to DNA breaks: leaving a mark on genome integrity. Annual review of biochemistry $82,55-80$.

Smeenk, G., Wiegant, W.W., Marteijn, J.A., Luijsterburg, M.S., Sroczynski, N., Costelloe, T., Romeijn, R.J., Pastink, A., Mailand, N., Vermeulen, W., et al. 2013. Poly(ADPribosylation links the chromatin remodeler SMARCA5/SNF2H to RNF168-dependent DNA damage signaling. Journal of cell science 126, 889-903.

Smeenk, G., Wiegant, W.W., Vrolijk, H., Solari, A.P., Pastink, A., and van Attikum, H. 2010. The NuRD chromatin-remodeling complex regulates signaling and repair of DNA damage. The Journal of cell biology 190, 741-749.

Soria, G., Polo, S.E., and Almouzni, G. 2012. Prime, repair, restore: the active role of chromatin in the DNA damage response. Mol Cell 46, 722-734.

Stewart, G.S., Panier, S., Townsend, K., Al-Hakim, A.K., Kolas, N.K., Miller, E.S., Nakada, S., Ylanko, J., Olivarius, S., Mendez, M., et al. 2009. The RIDDLE Syndrome Protein Mediates a Ubiquitin-Dependent Signaling Cascade at Sites of DNA Damage. Cell 136, 420-434.

Stiff, T., O'Driscoll, M., Rief, N., Iwabuchi, K., Lobrich, M., and Jeggo, P.A. 2004. ATM and DNA-PK function redundantly to phosphorylate $\mathrm{H} 2 \mathrm{AX}$ after exposure to ionizing radiation. Cancer research 64, 2390-2396.

Stucki, M., Clapperton, J.A., Mohammad, D., Yaffe, M.B., Smerdon, S.J., and Jackson, S.P. 2005. MDC1 directly binds phosphorylated histone H2AX to regulate cellular responses to DNA double-strand breaks. Cell 123, 1213-1226. 
Sun, Y.L., Jiang, X.F., Xu, Y., Ayrapetov, M.K., Moreau, L.A., Whetstine, J.R., and Price, B.D. 2009. Histone H3 methylation links DNA damage detection to activation of the tumour suppressor Tip60. Nature cell biology 11, 1376-U1273.

Suto, R.K., Clarkson, M.J., Tremethick, D.J., and Luger, K. 2000. Crystal structure of a nucleosome core particle containing the variant histone H2A.Z. Nature structural biology 7, 1121-1124.

Taherbhoy, A.M., Huang, O.W., and Cochran, A.G. 2015. BMI1-RING1B is an autoinhibited RING E3 ubiquitin ligase. Nature communications 6.

Tang, J.B., Cho, N.W., Cui, G.F., Manion, E.M., Shanbhag, N.M., Botuyan, M.V., Mer, G., and Greenberg, R.A. 2013. Acetylation limits 53BP1 association with damaged chromatin to promote homologous recombination. Nature structural \& molecular biology 20, 317-325.

Taty-Taty, G.C., Courilleau, C., Quaranta, M., Carayon, A., Chailleux, C., Aymard, F., Trouche, D., and Canitrot, Y. 2014. H2A.Z depletion impairs proliferation and viability but not DNA double-strand breaks repair in human immortalized and tumoral cell lines. Cell Cycle 13, 399-407.

Thorslund, T., Ripplinger, A., Hoffmann, S., Wild, T., Uckelmann, M., Villumsen, B., Narita, T., Sixma, T.K., Choudhary, C., Bekker-Jensen, S., et al. 2015. Histone H1 couples initiation and amplification of ubiquitin signalling after DNA damage. Nature 527, 389-393.

Timinszky, G., Till, S., Hassa, P.O., Hothorn, M., Kustatscher, G., Nijmeijer, B., Colombelli, J., Altmeyer, M., Stelzer, E.H.K., Scheffzek, K., et al. 2009. A macrodomaincontaining histone rearranges chromatin upon sensing PARP1 activation. Nature structural \& molecular biology 16, 923-U941.

Tjeertes, J.V., Miller, K.M., and Jackson, S.P. 2009. Screen for DNA-damage-responsive histone modifications identifies H3K9Ac and H3K56Ac in human cells. The EMBO journal 28, 1878-1889.

Toiber, D., Erdel, F., Bouazoune, K., Silberman, D.M., Zhong, L., Mulligan, P., Sebastian, C., Cosentino, C., Martinez-Pastor, B., Giacosa, S., et al. 2013. SIRT6 Recruits SNF2H to DNA Break Sites, Preventing Genomic Instability through Chromatin Remodeling. Mol Cell 51, 454-468.

Tremethick, D.J. 2007. Higher-order structures of chromatin: the elusive $30 \mathrm{~nm}$ fiber. Cell 128, 651-654. 
van Attikum, H., and Gasser, S.M. 2005. The histone code at DNA breaks: A guide to repair? Nat Rev Mol Cell Bio 6, 757-765.

Vempati, R.K., Jayani, R.S., Notani, D., Sengupta, A., Galande, S., and Haldar, D. 2010. p300-mediated Acetylation of Histone H3 Lysine 56 Functions in DNA Damage Response in Mammals. Journal of Biological Chemistry 285, 28553-28564.

Vidi, P.A., Liu, J., Salles, D., Jayaraman, S., Dorfman, G., Gray, M., Abad, P., Moghe, P.V., Irudayaraj, J.M., Wiesmuller, L., et al. 2014. NuMA promotes homologous recombination repair by regulating the accumulation of the ISWI ATPase SNF2h at DNA breaks. Nucleic acids research 42, 6365-6379.

Wakeman, T.P., Wang, Q.H., Feng, J.J., and Wang, X.F. 2012. Bat3 facilitates H3K79 dimethylation by DOT1L and promotes DNA damage-induced 53BP1 foci at G1/G2 cellcycle phases. Embo Journal 31, 2169-2181.

Wang, G.G., Allis, C.D., and Chi, P. 2007. Chromatin remodeling and cancer, part I: covalent histone modifications. Trends in molecular medicine 13, 363-372.

Wang, H., Wang, L., Erdjument-Bromage, H., Vidal, M., Tempst, P., Jones, R.S., and Zhang, Y. 2004. Role of histone H2A ubiquitination in Polycomb silencing. Nature 431, 873-878.

Weber, C.M., Henikoff, J.G., and Henikoff, S. 2010. H2A.Z nucleosomes enriched over active genes are homotypic. Nature structural \& molecular biology 17, 1500-U1136.

Wyrick, J.J., Kyriss, M.N., and Davis, W.B. 2012. Ascending the nucleosome face: recognition and function of structured domains in the histone $\mathrm{H} 2 \mathrm{~A}-\mathrm{H} 2 \mathrm{~B}$ dimer. Biochimica et biophysica acta 1819, 892-901.

Xiao, A., Li, H.T., Shechter, D., Ahn, S.H., Fabrizio, L.A., Erdjument-Bromage, H., Ishibe-Murakami, S., Wang, B., Tempst, P., Hofmann, K., et al. 2009. WSTF regulates the H2A.X DNA damage response via a novel tyrosine kinase activity. Nature 457, 57U57.

Xu, C., Xu, Y., Gursoy-Yuzugullu, O., and Price, B.D. 2012a. The histone variant macroH2A1.1 is recruited to DSBs through a mechanism involving PARP1. FEBS letters 586, 3920-3925.

Xu, Y., Ayrapetov, M.K., Xu, C., Gursoy-Yuzugullu, O., Hu, Y.D., and Price, B.D. 2012b. Histone H2A.Z Controls a Critical Chromatin Remodeling Step Required for DNA Double-Strand Break Repair. Mol Cell 48, 723-733.

$\mathrm{Xu}, \mathrm{Y}$., and Price, B.D. 2011. Chromatin dynamics and the repair of DNA double strand breaks. Cell Cycle 10, 261-267. 
Xu, Y., Sun, Y., Jiang, X., Ayrapetov, M.K., Moskwa, P., Yang, S., Weinstock, D.M., and Price, B.D. 2010. The p400 ATPase regulates nucleosome stability and chromatin ubiquitination during DNA repair. The Journal of cell biology 191, 31-43.

Yan, Q.S., Dutt, S., Xu, R., Graves, K., Juszczynski, P., Manis, J.P., and Shipp, M.A. 2009. BBAP Monoubiquitylates Histone H4 at Lysine 91 and Selectively Modulates the DNA Damage Response. Mol Cell 36, 110-120.

Yang, X., Li, L., Liang, J., Shi, L., Yang, J., Yi, X., Zhang, D., Han, X., Yu, N., and Shang, Y. 2013. Histone acetyltransferase 1 promotes homologous recombination in DNA repair by facilitating histone turnover. The Journal of biological chemistry 288 , 18271-18282.

Ziv, Y., Bielopolski, D., Galanty, Y., Lukas, C., Taya, Y., Schultz, D.C., Lukas, J., BekkerJensen, S., Bartek, J., and Shiloh, Y. 2006. Chromatin relaxation in response to DNA double-strand breaks is modulated by a novel ATM and KAP-1 dependent pathway. Nature cell biology 8, 870-U142. 


\begin{tabular}{|c|c|c|c|c|c|}
\hline Histones & Modifications & $\begin{array}{c}\text { Target } \\
\text { residues }\end{array}$ & $\begin{array}{c}\text { Writer } \\
\text { enzymes }\end{array}$ & $\begin{array}{c}\text { Functions in DSB } \\
\text { repair }\end{array}$ & References \\
\hline \multirow{4}{*}{$\mathrm{H} 2 \mathrm{~A}$} & Acetylation & K5 & TIP60 & $\begin{array}{l}\text { Involved in early } \\
\text { DSB response }\end{array}$ & (Beck et al. 2006) \\
\hline & Ubiquitylation & $\mathrm{K} 13 / 15$ & $\begin{array}{l}\text { RNF8/RNF1 } \\
68\end{array}$ & $\begin{array}{l}\text { 53BP1, BRCA1 } \\
\text { recruitment }\end{array}$ & $\begin{array}{c}\text { (Huen et al. 2007; Kolas et } \\
\text { al. 2007; Doil et al. 2009; } \\
\text { Gatti et al. 2012; Mattiroli et } \\
\text { al. 2012) } \\
\end{array}$ \\
\hline & Ubiquitylation & K118/119 & $\begin{array}{c}\text { RING1B/BMI } \\
1\end{array}$ & $\begin{array}{l}\text { Transcriptional } \\
\text { silencing at DSBs }\end{array}$ & $\begin{array}{l}\text { (de Napoles et al. 2004; } \\
\text { Wang et al. 2004; Huen et } \\
\text { al. 2007; Ismail et al. 2010; } \\
\text { Ginjala et al. 2011; Leung et } \\
\text { al. 2014) }\end{array}$ \\
\hline & Ubiquitylation & $\mathrm{K} 127 / 129$ & BRCA1 & N.D. & (Kalb et al. 2014) \\
\hline \multirow{7}{*}{$\mathrm{H} 2 \mathrm{AX}$} & Acetylation & K5 & TIP60 & $\begin{array}{l}\text { Regulation of } \mathrm{H} 2 \mathrm{AX}- \\
\text { Ub, HR repair }\end{array}$ & (Ikura et al. 2007) \\
\hline & Acetylation & K36 & CBP/p300 & $\begin{array}{l}\text { Ku recruitment for } \\
\text { NHEJ, regulation of } \\
\text { IR sensitivity }\end{array}$ & (Jiang et al. 2010) \\
\hline & Phosphorylation & S139 & $\begin{array}{l}\text { ATM, ATR, } \\
\text { DNA-PKcs }\end{array}$ & $\begin{array}{l}\text { Check point } \\
\text { activation, HR, } \\
\text { NHEJ proteins } \\
\text { recruitment }\end{array}$ & $\begin{array}{l}\text { (Rogakou et al. 1998; Paull } \\
\text { et al. 2000; Fernandez- } \\
\text { Capetillo et al. 2002; Stiff et } \\
\text { al. 2004) }\end{array}$ \\
\hline & Phosphorylation & Y142 & WSTF & $\begin{array}{l}\text { Switch between } \\
\text { DNA repair and } \\
\text { apoptosis }\end{array}$ & (Xiao et al. 2009) \\
\hline & Ubiquitylation & $\mathrm{K} 13 / 15$ & $\begin{array}{l}\text { RNF8/RNF1 } \\
68\end{array}$ & $\begin{array}{l}\text { 53BP1, BRCA1 } \\
\text { recruitment }\end{array}$ & $\begin{array}{l}\text { (Huen et al. 2007; Gatti et al. } \\
\text { 2012; Mattiroli et al. 2012; } \\
\text { Fradet-Turcotte et al. 2013) }\end{array}$ \\
\hline & Ubiquitylation & $\mathrm{K} 118 / 119$ & $\begin{array}{c}\text { RING1B/BMI } \\
1\end{array}$ & $\begin{array}{c}\text { Transcription } \\
\text { repression at DSB } \\
\text { sites, HR and NHEJ } \\
\text { repair }\end{array}$ & $\begin{array}{c}\text { (Huen et al. 2007; Facchino } \\
\text { et al. 2010; Chagraoui et al. } \\
\text { 2011; Ginjala et al. 2011; } \\
\text { Leung et al. 2014) }\end{array}$ \\
\hline & Sumoylation & N.D. & N.D. & N.D. & (Chen et al. 2013) \\
\hline H2A.Z & Ubiquitylation & N.D. & RNF168 & N.D. & (O'Connor et al. 2015) \\
\hline \multirow[b]{2}{*}{$\mathrm{H} 2 \mathrm{~B}$} & Phosphorylation & S14 & Mst1 kinase & $\begin{array}{c}\text { Chromatin } \\
\text { stabilization and } \\
\text { restoration post } \\
\text { repair } \\
\end{array}$ & $\begin{array}{l}\text { (Fernandez-Capetillo et al. } \\
\text { 2004; Rossetto et al. 2010) }\end{array}$ \\
\hline & Ubiquitylation & K120 & $\begin{array}{c}\text { RNF } \\
\text { 20/RNF40 }\end{array}$ & $\begin{array}{c}\text { NHEJ and HR } \\
\text { proteins recruitment, } \\
\text { Chromatin } \\
\text { decompaction for } \\
\text { repair }\end{array}$ & $\begin{array}{c}\text { (Moyal et al. 2011; } \\
\text { Nakamura et al. 2011) }\end{array}$ \\
\hline $\mathrm{H} 3$ & Acetylation & K14 & $\begin{array}{l}\text { GCN5, } \\
\text { requires } \\
\text { HMGN }\end{array}$ & $\begin{array}{c}\text { Promotes BRG1 } \\
\text { binding to } \mathrm{YH} 2 \mathrm{AX} \\
\text { NCPs, ATM binding } \\
\text { to damaged } \\
\text { chromatin, regulates } \\
\text { activity of ATM } \\
\text { kinase }\end{array}$ & $\begin{array}{l}\text { (Kim et al. 2009; Lee et al. } \\
\text { 2010) }\end{array}$ \\
\hline
\end{tabular}




\begin{tabular}{|c|c|c|c|c|c|}
\hline & Acetylation & K18 & CBP, p300 & $\begin{array}{l}\text { NHEJ repair factor } \\
\text { Ku accumulation }\end{array}$ & (Ogiwara et al. 2011) \\
\hline & Acetylation & K23 & HAT1 & Promotes HR repair & (Yang et al. 2013) \\
\hline & Acetylation & K56 & CBP, p300 & $\begin{array}{l}\text { Promotes NHEJ } \\
\text { repair }\end{array}$ & $\begin{array}{l}\text { (Tjeertes et al. 2009; Miller } \\
\text { et al. 2010; Vempati et al. } \\
\text { 2010) }\end{array}$ \\
\hline & $\begin{array}{l}\text { Methylation } \\
\quad(\text { me3) }\end{array}$ & K9 & $\begin{array}{c}\text { Suv39h1/Suv } \\
39 \mathrm{~h} 2\end{array}$ & $\begin{array}{l}\text { ATM activation, } \\
\text { Stimulation of TIP60 } \\
\text { activity }\end{array}$ & $\begin{array}{c}\text { (Ayoub et al. 2008; Sun et } \\
\text { al. 2009; Bao 2011; Xu and } \\
\text { Price 2011; Ayrapetov et al. } \\
\text { 2014) }\end{array}$ \\
\hline & $\begin{array}{l}\text { Methylation } \\
\quad(\mathrm{me} 2)\end{array}$ & K36 & $\begin{array}{c}\text { Metnase/SE } \\
\text { TMAR }\end{array}$ & $\begin{array}{l}\text { NBS1 and Ku } \\
\text { accumulation, } \\
\text { promotes NHEJ } \\
\text { repair }\end{array}$ & (Fnu et al. 2011) \\
\hline & $\begin{array}{l}\text { Methylation } \\
\quad(\mathrm{me} 3)\end{array}$ & K36 & SETD2 & $\begin{array}{l}\text { HR repair of DSBs } \\
\text { within } \\
\text { transcriptionally } \\
\text { active sites }\end{array}$ & $\begin{array}{l}\text { (Aymard et al. 2014; } \\
\text { Carvalho et al. 2014; Pfister } \\
\text { et al. 2014) }\end{array}$ \\
\hline & $\begin{array}{l}\text { Methylation } \\
\text { (me2) }\end{array}$ & K79 & Dot1L & $\begin{array}{c}\text { Recruits 53BP1 to } \\
\text { DSB site }\end{array}$ & $\begin{array}{c}\text { (Huyen et al. 2004; } \\
\text { Wakeman et al. 2012) }\end{array}$ \\
\hline \multirow{5}{*}{$\mathrm{H} 4$} & Acetylation & $\begin{array}{l}\mathrm{K} 5, \mathrm{~K} 8 \\
\mathrm{~K} 12\end{array}$ & $\begin{array}{l}\text { CBP/p300, } \\
\text { TIP60 (NuA4 } \\
\text { complex) }\end{array}$ & $\begin{array}{l}\text { Ku proteins } \\
\text { recruitment for } \\
\text { NHEJ repair, } \\
\text { chromatin relaxation }\end{array}$ & (Ogiwara et al. 2011) \\
\hline & Acetylation & K16 & $\begin{array}{l}\text { MOF, TIP60 } \\
\text { (NuA4 } \\
\text { complex) }\end{array}$ & $\begin{array}{l}\text { MDC1 binding to } \\
\text { YH2AX, reduced } \\
\text { 53BP1 binding to } \\
\text { chromatin, BRCA1 } \\
\text { recruitment, H2A.Z } \\
\text { exchange, } \\
\text { transcriptional } \\
\text { repression, } \\
\text { chromatin } \\
\text { condensation, } \\
\text { ZMYND8 binding }\end{array}$ & $\begin{array}{l}\text { (Gupta et al. 2005; Chailleux } \\
\text { et al. 2010; Li et al. 2010; } \\
\text { Sharma et al. 2010; Hsiao } \\
\text { and Mizzen 2013; Tang et } \\
\text { al. 2013; Gong et al. 2015) }\end{array}$ \\
\hline & $\begin{array}{l}\text { Methylation(me1 } \\
\text { /2) }\end{array}$ & K20 & $\begin{array}{l}\text { PRSET7/Set } \\
\text { 8, MMSET }\end{array}$ & 53BP1 recruitment & $\begin{array}{l}\text { (Botuyan et al. 2006; Oda et } \\
\text { al. 2010; Hartlerode et al. } \\
\text { 2012; Hsiao and Mizzen } \\
\text { 2013) }\end{array}$ \\
\hline & Neddylation & $\mathrm{N}$-tail & RNF111 & RNF168 recruitment & (Ma et al. 2013) \\
\hline & Ubiquitylation & K91 & BBAP & $\begin{array}{l}\text { Required for } \\
\text { induction of } \\
\text { H4K20me to } \\
\text { promote 53BP1 } \\
\text { recruitment } \\
\end{array}$ & (Yan et al. 2009) \\
\hline $\mathrm{H} 1$ & Ubiquitylation & N.D. & RNF8 & $\begin{array}{l}\text { Forms K-63 linked } \\
\text { Ub chains for } \\
\text { RNF168 recruitment }\end{array}$ & (Thorslund et al. 2015) \\
\hline
\end{tabular}

Table 1. Histone PTMs associated with DSB repair in mammalian cells. N.D.= Not determined. 


\begin{tabular}{|c|c|c|c|c|}
\hline $\begin{array}{l}\text { Acidic patch } \\
\text { interacting } \\
\text { proteins }\end{array}$ & $\begin{array}{c}\text { Co-structures } \\
\text { with } \\
\text { nucleosome }\end{array}$ & $\begin{array}{c}\text { Histone PTMs } \\
\text { involved }\end{array}$ & Involvement in pathways & References \\
\hline LANA & Yes & No & Viral infection & (Barbera et al. 2006) \\
\hline IL-33 & Yes & No & Nuclear signaling & (Roussel et al. 2008) \\
\hline RCC1 & Yes & No & $\begin{array}{c}\text { Chromosome } \\
\text { condensation }\end{array}$ & (Makde et al. 2010) \\
\hline HMGN2 & Yes & No & Chromatin structure & (Kato et al. 2011) \\
\hline SIR3 & Yes & No & Transcription silencing & (Armache et al. 2011) \\
\hline CENP-C & Yes & No & Kinetochore assembly & (Kato et al. 2013) \\
\hline $\begin{array}{c}\text { RING1B/BMI1 } \\
\text { (PRC1) }\end{array}$ & Yes & $\begin{array}{c}\text { H2A/X } \\
\text { K118/119 Ub }\end{array}$ & DDR signaling & $\begin{array}{c}\text { (Chen et al. 2013; Leung et al. } \\
\text { 2014; McGinty et al. 2014) }\end{array}$ \\
\hline RNF168 & Not shown & $\begin{array}{c}\text { H2A/X K13/15 } \\
\text { Ub, H2AZ }\end{array}$ & DDR signaling & $\begin{array}{c}\text { (Chen et al. 2013; Leung et al. } \\
\text { 2014; Mattiroli et al. 2014) }\end{array}$ \\
\hline BRCA1 & Predicted & $\begin{array}{c}\text { H2A K127/129 } \\
\text { Ub }\end{array}$ & DDR signaling & $\begin{array}{c}\text { (Kalb et al. 2014; McGinty et } \\
\text { al. 2014) }\end{array}$ \\
\hline IE-1 & Yes & No & hCMV infection & (Fang et al. 2016) \\
\hline H4 N'-tail & Yes & No & Chromatin structure & (Luger et al. 1997) \\
\hline
\end{tabular}

Table 2. Nucleosome acidic patch interacting factors. 


\section{Figure Legend}

Fig. 1. DNA damage signaling within chromatin

A. The MRN complex senses the DSB and recruits and activates ATM resulting in phosphorylation of $\mathrm{H} 2 \mathrm{AX}$ (i.e. $\gamma \mathrm{H} 2 \mathrm{AX}$ ). $\gamma \mathrm{H} 2 \mathrm{AX}$ is bound by MDC1, which interacts with MRN-ATM, which sets up an amplification signal on chromatin. Phosphorylated MDC1 recruits the Ubiquitin E3 ligase RNF8 that targets $\mathrm{H} 1$ linker histones. Ubiquitylated $\mathrm{H} 1$ promotes recruitment of the ubiquitin $\mathrm{E} 3$ ligase RNF168. RNF168 dependent ubiquitiylation of $H 2 A$ and $H 2 A X$ promotes accumulation of DSB repair proteins to sites of damage. $\mathrm{P}=$ phosphorylation, $\mathrm{Ub}$ = Ubiquitylation, MRN = Mre11-Rad50-Nbs1 complex .

B. Damage-induced histone ubiquitylations. X-ray crystal structure of a nucleosome core particle of Xenopus was retrieved from protein data bank (PDB code $1 \mathrm{AOI}$ ) and modelled in Pymol. Locations of lysine residues on the exposed nucleosomal surface are marked in dark blue. Histone tails are structurally unresolved so are not depicted. Known damage-induced ubiquitylated lysines are indicated as Ub. DNA - grey, histones - pale cyan, lysines - dark blue, ubiquitin (Ub) - light blue.

Fig. 2. Involvement of the nucleosome acidic patch in the DDR.

A. Structural position of the negatively charged acidic patch residues (shown in red) within the nucleosome (PDB 1AOI). The structure was colored and modelled in Pymol. B. Sequence alignment of acidic patch containing segment (50-101 amino acids) of histone $\mathrm{H} 2 \mathrm{~A}$ and its variants. The acidic patch residues of $\mathrm{H} 2 \mathrm{~A}$ 
(E56, E61, E64, D90, E91and E92) are highlighted in red. Residues that are conserved among all the four $\mathrm{H} 2 \mathrm{~A}$ variants are marked in brown boxes.

C, D and E. The E3 ligases RNF168, RING1B/BMI1 and BRCA1 require the nucleosome acidic patch for site-specific ubiquitylations on K15, K119 and K127/129 of H2A respectively. H2A K15-Ub by RNF168 promotes 53BP1 recruitment (dual recognition by $\mathrm{H} 2 \mathrm{~A} \mathrm{~K} 15 \mathrm{Ub}$ and $\mathrm{H} 4 \mathrm{~K} 2 \mathrm{Ome} 2$ ) to facilitate NHEJ and block HR repair. F. The acidic patch promotes $H 2 A Z$ exchange and removal at DSB site. Following DSB, the p400 subunit of NuA-TIP60 exchanges H2AH2B dimers for H2AZ-H2B. The extended acidic patch of H2AZ favors H4-tail interaction to stabilize nucleosomes and form compact chromatin. ANP32E then removes the $\mathrm{H} 2 \mathrm{AZ}-\mathrm{H} 2 \mathrm{~B}$ dimer from the nucleosome to promote $\mathrm{H} 4$ acetylation and open chromatin for HR repair. G. H2AZ is ubiquitylated by RNF168, the function of which is unclear.

\section{Fig. 3. Nucleosome acidic patch interacting proteins}

The acidic patch is a central hub for nucleosome interactions for multiple proteins involved in diverse biological processes. The crystal structure of NCP was retrieved from protein data bank (PDB code 1AOI) and modelled in Pymol. Color coding is as follows: DNA = grey, histones $=$ pale cyan, acidic patch $=$ red . 
Fig.1

A
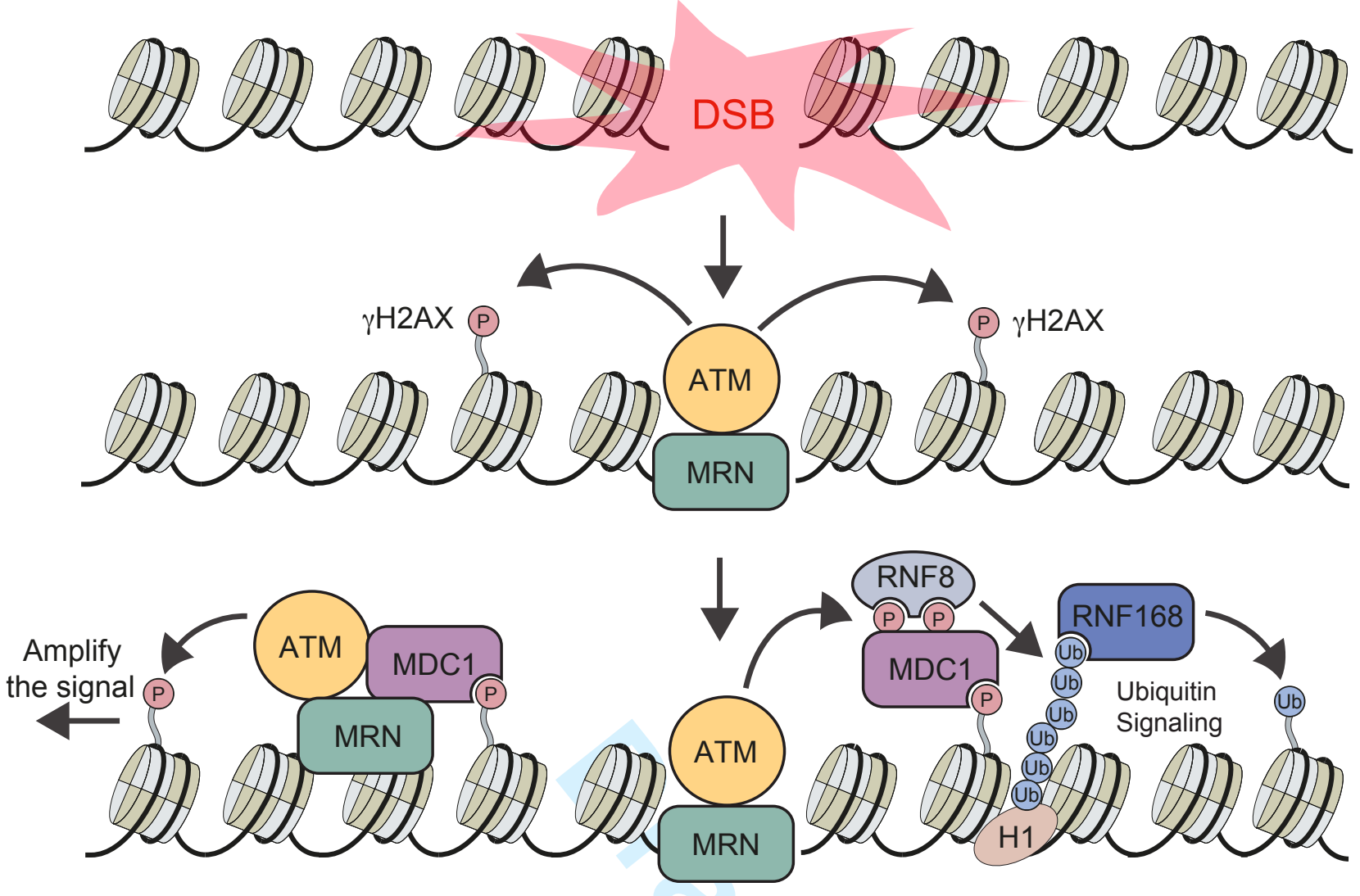

B

Nucleosome structure

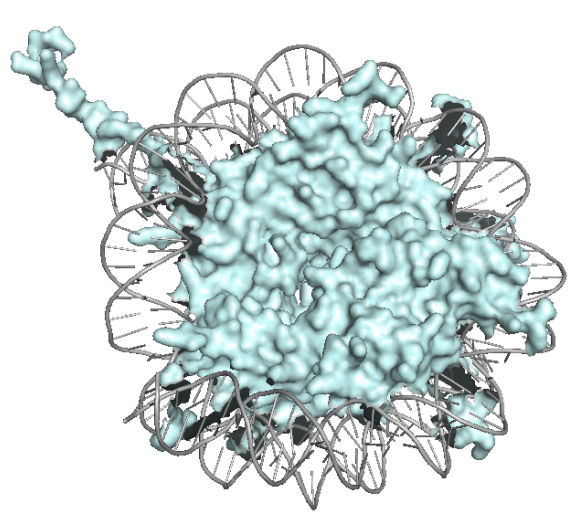

DNA
Surface Lysine residues

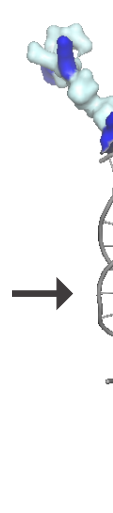

Core histones
Ubiquitylated Lysines in DDR

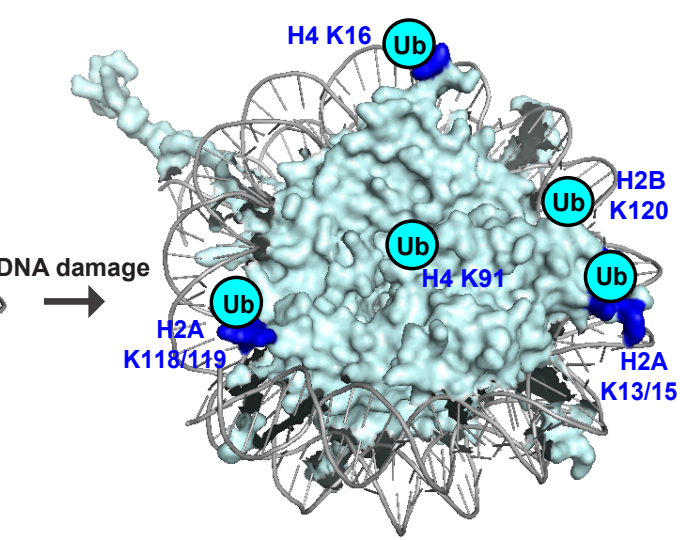

Lysines 
Fig.2

A

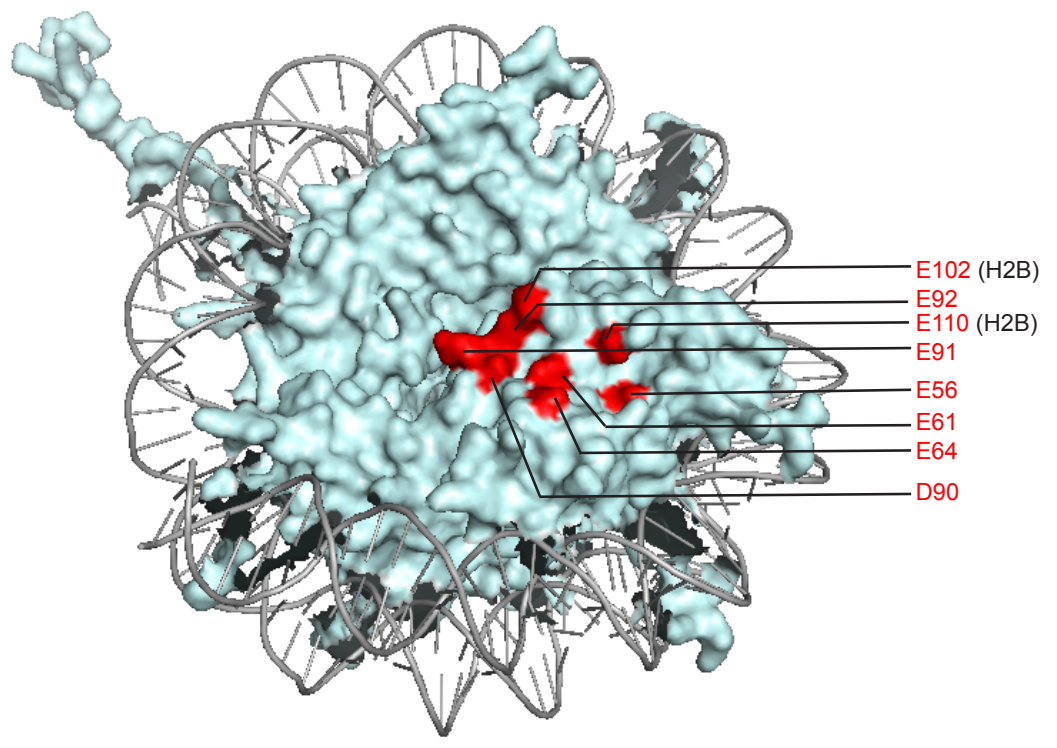

B
C

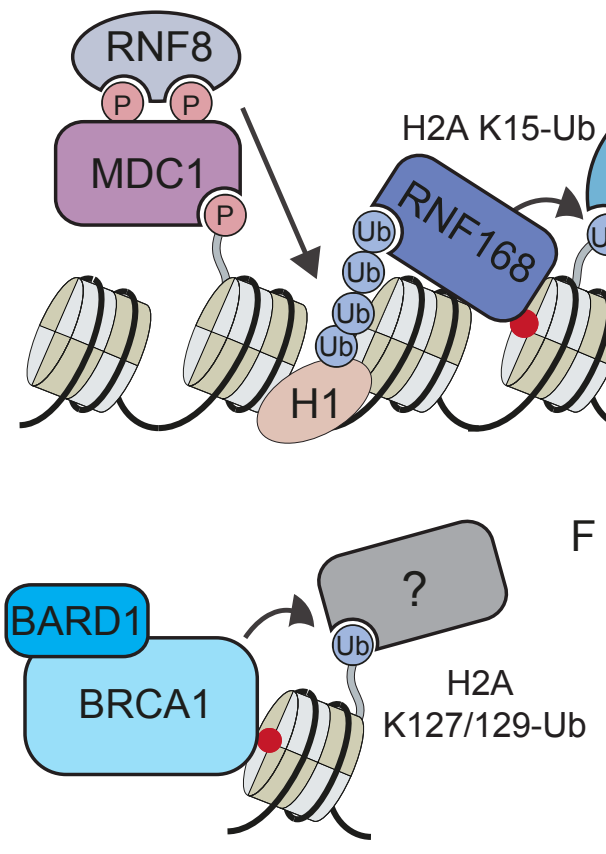

$\mathrm{F}$

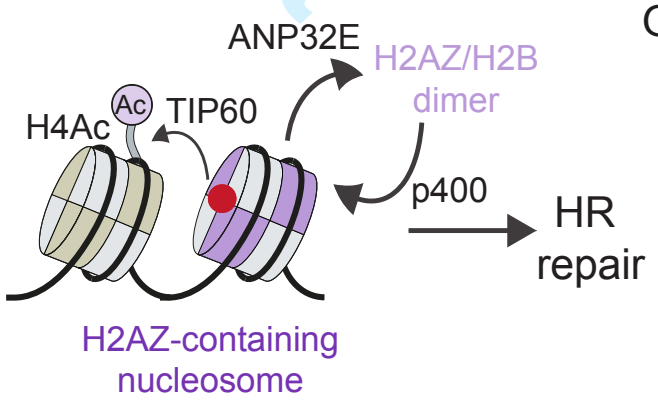
nucleosome

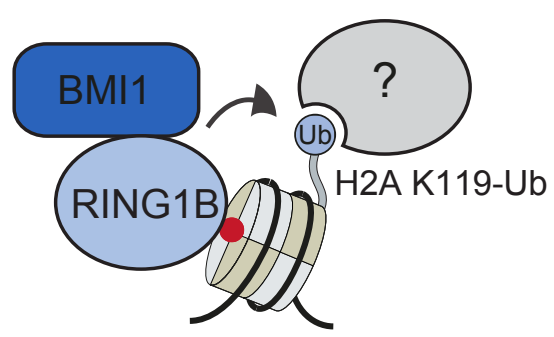

G

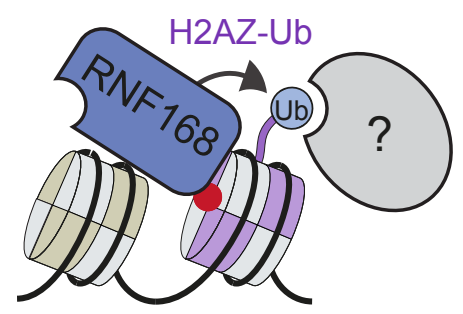


Fig.3

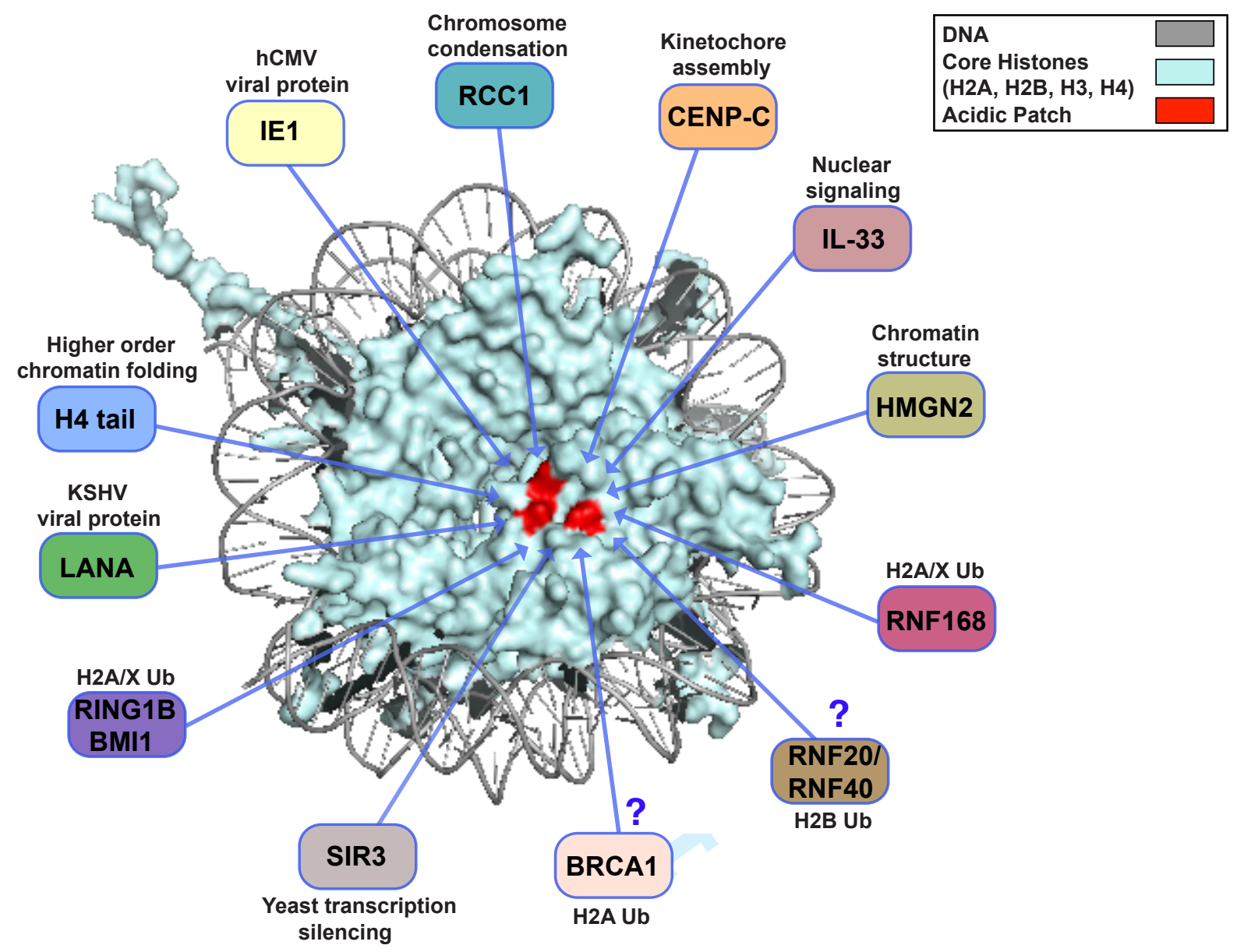

